\title{
LUKIŠKIŲ AIKŠTE் - SOCIALINIO UŽSAKYMO EVOLIUCIJA. PAMINKLAS LAISVĖS KOVŲ DALYVIAMS AR SIMBOLIS „LAISVE்“?
}

\author{
Algis Vyšniūnas \\ Urbanistikos katedra, Vilniaus Gedimino technikos universitetas, \\ Pylimo g. 26/Trakug. 1, LT-01132 Vilnius, Lietuva \\ El.paštasalgis.vysniunas@gmail.com \\ Itteikta 20081023
}

Santrauka. 2008 m. paskelbtas Lukiškių aikštès sutvarkymo ir simbolio „Laisve““ projekto sukūrimo konkursas. Vertinimo komisija išrinko 7 geriausius konkursinius projektus. Šie rezultatai sukèlè daug diskusijų, nes neaišku, ar tikrai pasiektas pagrindinis konkurso tikslas - ịprasminti Laisvès kovas ir pagerbti tų kovų dalyvių atminimą? Nors yra labai konkretus LR Seimo nutarimas „Dèl Lukiškių aikštès funkcijų“, vis tiek lieka neaiškus Lukiškių aikštės statusas: ar ji yra valstybinio rango aikštè, ar paprasta vieša savivaldybės erdvė? Kai neaiškus aikštės statusas, neaiškus ir tikslo realizavimo mechanizmas bei priemonès. Straispnyje apžvelgiami pagrindiniai Lukiškių aikštès urbanistinès plètros etapai, j̨vertinant ne tik realizacijas, bet ir visas idèjas, profesines koncepcijas. Pagrindinis straipsnio tikslas - atskleisti Lukiškių aikštės formavimo mechanizmus, bet ne komentuoti atskirus meninius pasiūlymus. Straipsnyje nekomentuojami atskirų suinteresuotų socialinių ir politinių grupių pareiškimai, taip pat tariamai moksliniai pranešimai viešųjų ryšių renginiuose ir akcijose. Taip pat nediskutuojama apie grynojo meno paskirtį ir santykị su mokslu ir politika. Išvadose pateikiami Lukiškių aikštès urbanistinio formavimo ir paminklo Laisvės kovotojams statymo principai.

Reikšminiai žodžiai: nacionalinė savigarba, architektūrinis konkursas, viešieji ryšiai, meninis akcentas, simbolis, paminklas, aikštė, skveras, urbanistinė struktūra, paminklas Laisvès kovų dalyviams.

Mūsu visuomenè šiandien prisitaikyma ir kolaboravima sovietmečiu vertina kaip gédingiausia Lietuvos istorijos momentą. Neseniai atliktoje gyventoju apklausoje į klausima, ko iš savo šalies praeities reikètų labiausiai gèdytis, daugiausiai apklaustuju pasirinko atsakymą: kolaboravimo su okupantais, išdavysčiu, prisitaikymo.

Nerija Putinaitè (2007)

Susvetimëjusios visuomenès piliečiai nebesijaučia įpareigoti ankstesniu kartu puoselètiems idealams ir ju asmeniniame gyvenime ịsigali kultūrinès ir politines prasmès, vengiant bet kokiu didesniu nuorodu i tautinį tapatumą.

Alvydas Jokubaitis (2006)

\section{Ivadas}

Straipsnio pavadinime retorinis klausimas yra labai sudètingas, nes atsakymas yra susijęs ne su elementariais pasirinkimo variantais, bet su vertybine orientacija. Atsakymai ị šị klausimą tèra du, bet jie principiniai - tai yra arba valstybinio rango paminklas, arba abstraktus meninis akcentas, kurio semantinis tekstas dažniausiai perskaitomas tik taikant verbalines konstrukcijas. Aukšta meninè kokybė yra privaloma abiem atvejais, todèl tai nèra pagrindinis kriterijus (taip pat kaip ir sti- listika), kalbant apie Lukiškių aikštę, kaip apie pagrindinę Lietuvos sostinès aikštę. Problema yra fundamentinè, nes valstybinio rango ženklų, simbolių, paminklų problema yra kaip niekad aktuali. Tai yra valstybinès politikos dalis, todèl reikia labai aiškiai skirti, kur baigiasi menininko meninès ambicijos ir kur prasideda visos nacijos nacionalinis identitetas, pasididžiavimas, savigarba. 
Ši problema nèra tokia paprasta, kaip atrodo iš pirmo žvilgsnio. Geriausias pavyzdys, i̇rodantis paminklo reikšmę politiniam kontekstui - 2007 metų ỉvykiai Taline (Estija), estų valdžiai pabandžius perkelti rusų kareivių palaikus ir paminklą į kitą vietą. Todèl reikia sugebèti atskirti pagarbą vertybèms, politinę demagogiją, populistinius viešujų ryšių elementus, destrukcines politines technologijas.

Nacija, neturinti etnokultūrinès saviidentifikacijos problemų, dažniausiai turi svarbiausią valstybès vietą su visa tam tikslui skirta atributika ir simboliais. Pvz., Latvijos sostineje Rygoje stovintis Laisvés paminklas (skulptorius K. Zale) niekam nekelia jokių abejonių. Analogiškai yra visoje Europoje: Romoje - Tẻvynès altorius, paminklas Džiuzepė Garibaldi, Helsinkyje paminklas generolui Manerheimui, Londone - Trafalgaro aikšte su paminklu admirolui Nelsonui, Paryžiuje Triumfo arka Žvaigždès aikštėje, Jerevane - skulptoriaus A. Tarchaniano paminklas armènams (1915 metų genocido aukoms) ir architekto R. Israeliano suprojektuotas kompleksas, skirtas pergalei prieš turkus Sardarapato mūšyje 1918 metais ir t. t. Tu šaliu piliečiams minèti paminklai ir simboliai kelia pasididžiavimą. Tai yra savaime suprantamas dalykas save gerbiančioje valstybeje. $\mathrm{O}$ ką jau kalbèti apie Laisvès statulą Niujorke, Kristaus skulptūrą Rio de Žaneire, Mamajevo kurganą Volgograde, taip pat begalę pompastiškų paminklų holokausto aukoms Izraelyje (Young 1993).

Lietuvoje tokios vietos nèra, o kitų valstybių vadovai per oficialų vizitą vežami ị Antakalnio kapines padèti gèliu prie paminklo Sausio 13-osios aukoms. Neatsitiktinai Lukiškių aikštès konkurso sąlygų apraše (2008) prašoma numatyti vietas reprezentacinei funkcijai.

Lukiškių aikštės istoriją galima traktuoti ne tik kaip urbanistinès plètros istoriją, bet ir kaip valstybinio rango ženklų istoriją. Kai tik Lietuva pateko ị Rusijos imperijos sudètị neatsitiktinai pirmiausia pradèti naikinti Lietuvos valstybingumo ženklai (nugriautas Vilniaus pilių kompleksas kartu su visa gynybinès sienos sistema, Lietuvos Metrika ir Statutas išvežti ị Maskvą, uždarytas universitetas ir t. t.), jau nekalbant apie žudymus ir plešimus. Neatsitiktinai tiek Rusijos imperija, tiek SSSR Lukiškių aikšteje ir prieigose (kaip ir visoje Lietuvoje) state savo ženklus (paminklas komunizmo ideologui V. Leninui) ir objektus (Lukiškių kalèjimas, SSSR KGB pastatas).

Todèl bet kokie veiksmai keičiant vienus ženklus ar paminklus kitais yra neišvengiamai susiję su situacija, reikalaujančia moralinio pasirinkimo. Tai ypač akivaizdu Lukiškių aikšteje Vilniuje. Šito nepripažįsta (arba atvirai vengia diskutuoti šiais klausimais) žmonès, kuriems būdingi su avangardinèmis kultūromis siejami požiūriai ir elgesio modeliai. Ne paskutineje vietoje yra ir individo pasaulezžiūros sistema, todèl neturètų stebinti žmonių, lojalių buvusiam sovietiniam režimui, neigiamas požiūris ị Lukiškių aikštę, kaip ị svarbiausią valstybės aikštę su paminklu Laisvès kovų dalyviams. Tokių žmonių yra nemažai ir jie ne tik aktyviai dalyvauja ivairiuose problemos svarstymo etapuose ir lygmenyse (veda seminarus, rašo straipsnius, dalyvauja vertinimo komisijų veikloje ir t. t.), bet dažniausiai priima esminius politinius sprendimus. Tai tik įrodo, kad dabar vykstančios diskusijos apie Lukiškių aikštès ateitị nèra tik meninio pobūdžio diskusijos.

Šiuo metu Lukiškių aikštėje stovi akmeninè plokštè, kurioje yra užrašas Šioje aikštėje bus įamžintas $\mathrm{Ne}$ žinomojo partizano ir Kovotojo dèl Lietuvos laisvés atminimas. $1995 \mathrm{~m}$. gegužès $20 \mathrm{~d}$. Aiškiai ir logiškai suformuluotas galutinis tikslas. Šio tikslo realizavimo mechanizmas dèl biurokratinès veiklos specifikos yra dokumentuotas, todèl iš dalies galima teigti, kad nuo šio momento Lukiškiu aikštès istorija iš dalies yra ne tik architektūrinių idejų , bet ir socialinio užsakymo ir viešojo administravimo istorija. Nuo pat $1990 \mathrm{~m}$. surengta daug konkursų, bet jokio realaus rezultato nèra, nebent rezultato nebuvimas ir yra kai kurių politinių jègų veiklos rezultatas.

Pagrindinis straipsnio tikslas - atskleisti Lukiškių aikštess formavimo mechanizmus, bet ne komentuoti atskirus meninius pasiūlymus. Straipsnyje nekomentuojami atskirų suinteresuotų socialinių ir politinių grupių pareiškimai, taip pat nekomentuojami tariamai moksliniai pranešimai viešujų ryšių renginiuose ir akcijose.

\section{Lukiškių aikštė kaip erdvès tipas. Viešosios erd- vès samprata. Erdvès tipas ir funkcija}

Pirmiausia reikètų išsiaiškinti - ką reiškia žodis aikšté? Šis žodis gali turèti kelias prasmes. Plačioji prasmè - tai didelis tuščias plotas. Šia prasme aikštès sąvoka tinka bet kokios konfigūracijos ir bet kokio dydžio teritorijai netgi ne mieste (šia prasme vartojamas ir terminas futbolo aikštè). Siauroji prasmè - tai erdvès tipas su labai aiškiomis ribomis. Šia prasme aikštès sąvoka labiau tinka miestui (kokybinius aikštès aspektus labai plačiai nagrinejjo L. Krier). Tai yra architektūrinė sąvoka, kartu tai yra meninè priemone ir kūrybos objektas. Šiuo aspektu yra aiški kriterijų sistema - urbanistinè struktūra, kuri yra individuali kiekvienam miestui. Čia įmanoma 
profesionali diskusija tarp architektų ir urbanistų. Susitarimo išraiška - konkretus projektas.

Reikia skirti aikštes ir pagal administracinę hierarchiją - seniūnijos (pvz., Ugnijos aikštè Pašilaičiuose Vilniuje), savivaldybès (Rotušès aikštè), valstybès sostinès (Nepriklausomybès aikštè prie LR Seimo), valstybès (Lukiškių aikštè) ir t. t. Aikštès rangas lemia ir priemones. Visais minètais aspektais turi būti labai konkretus aiškumas.

L. Krier savo knygoje Houses, palaces, cities (1984) labai aiškiai skiria sąvokas, kai kalba apie visuomenines (viešąsias) erdves. Kartu labai aiškiai pabrèžiamas skirtumas tarp lokalių mazgų (local nodes) ir bendramiestinès reikšmès (sostinès) (metropolitan nodes) priklausančių nuo urbanistinès struktūros. Lokalūs mazgai (local nodes) - tai turgaus aikštė (piazza), statinys sankryžoje arba forume (tetrapylon), nedidelè aikštė (piazzetta), kiemas (court). Bendramiestinès reikšmès (sostinès) mazgai - tai didelè aikštè (piazzale), skveras (square), parkas (park), kapinès (cemetery). Kiti viešųu erdvių tipai (gatvè, pasažas, alèja, takas, galerija, kolonada, aveniu, bulvaras, krantinès ir t. t.) nèra mūsu dèmesio objektas.

Todèl logiška išvada, kad Lukiškių aikštè - pagrindinè valstybès aikštė, esanti Vilniaus mieste, t. y. sostinèje. Pagal L. Krier tai būtų piazzale (didelè aikštė) atvejis.

Kraštovaizdžio architektai R. Pilkauskas ir A. Žickis (1996) suplaka kelis aspektus ị vieną krūvą. Anot jų, Lukiškių aikštè (piazzale) - tai yra centrinis sostinès skveras (square - garden) su simboliniu kapu (cemete$r y$ ). Ko gero, tai yra būtent taip, nes straipsnyje Vilniaus kapiniu plètotè (Pilkauskas, Žickis 1996a) pateiktas Lukiškių aikštes su simboliniu partizano kapu projektinis pasiūlymas. Kitame straipsnyje Centrinis sostines skveras (Pilkauskas, Žickis 1996b) architektai R. Pilkauskas ir A. Žickis Lukiškių aikštę jau traktuoja kaip skverą, netgi lygina ji su visiškai nelyginamu Centriniu Niujorko parku, kurio plotas 300 ha.

Tokia traktuočių ívairové paaiškinama tuo, kad neidentifikuota „viešosios erdvès“ samprata, todèl dažnai erdvès tipas painiojamas su funkcija. Egzistuoja mitas, kad valstybinio rango aikšte, sukonstruota pagal klasikinius urbanistikos principus, automatiškai yra nehumaniška, neprieinama žmonėms, todèl nèra europietiška „viešoji erdve““. Vakarų Europos praktika rodo, kad svarbiausios aikštès, sukonstruotos pagal klasikinius urbanistinès kompozicijos principus (dominuoja ašis, geometriniame centre yra monumentas ir pan.), yra ypač populiarios, daugiafunkcès, atlieka kasdieninę „viešosios erdvès“ paskirtị. Kaip sėkmingą realizuotos viešosios erdvės pavyzdi profesorius Jan Gehl nurodo (Gehl, Gemzøe 2003) Paryžiaus Vandomų aikštę (Place Vandôme Paris, France. Architect Pierre Prunet, 1991-1992), kurioje sèkmingai suderinti pessčiųjų ir transporto interesai.

Robert Cowan 2005 metais išleistame Urbanistikos žodyne (Cowan 2005) viešąja erdve laiko visas teritorijas (nesvarbu dydis, konfigūracija, planavimo principai), $\mathfrak{i}$ kurias gali legaliai patekti bet kas ir bet kada be jokių trukdymų.

Aikštė yra erdvės tipas, o viešoji erdvė tèra funkcija. Šitą aiškiai suvokia Viešųjų erdvių tyrimų centro Kopenhagoje profesorius Jan Gehl, kuris savo knygose (Gehl, Gemzøe 2003; Gehl et al. 2006) kalba apie ịvairios paskirties neprivatizuotus žemès plotus mieste, bet nekomentuoja erdvės tipo, meninès kokybės, proporcijų ir pan. Svarbu socialinis scenarijus, kad tokiose erdvėse nebūtų transporto, triukšmo, būtų saugu, augtų medžiai ir pan.

Lukiškių aikštės Vilniuje atveju egzistuoja visiška painiava erdvinio karkaso nominalių erdvių hierarchijoje, todèl skirtingai suprantamas galutinis rezultatas. Tai, kas vienam piliečiui yra nacionalinès svarbos reikalas (Laivès kovų ịprasminimas), kitam tèra eilinis ūkinis uždavinys (požeminis garažas, fontanai, gazonai ir pan.). Tokia situacija nebestebina, kai išnagrinèjami užduoties formulavimo ir politinių sprendimų prièmimo mechanizmai, Lukiškių aikštès konkurso sąlygos ir vertinimo komisijos sudètis.

\section{Problemos identifikavimas, užduoties formulavimas}

Egzistuoja socialinis politinis aspektas. Labai svarbu, kas identifikuoja problemą, formuluoja užduotį. Siekiant pagrindinio tikslo, reikia tam tikros politinès kultūros brandos, lemiančios valstybingumo sandarą. Tikslo siekimo priemonès priklauso ne tik nuo materialinių išteklių, bet ir nuo mentaliteto. Šioje vietoje tiktų L. Balcerovičiaus citata (Balcerowicz 1998):

Egzistuoja tam tikra psichologiškai identifikuojama viršutinè sugebèjimu isisavinti informaciją riba. Kiekvieną visuomenę iš principo galima apibrèžti pagal šio pobūdžio ribų bendrą lygị bei pagal statistinị individų sugebëjimų pasiskirstymą šiose ribose.

Tik visiškai nieko nesusigaudantis politinèje visuomenès struktūroje žmogus gali neigti, kad sprendžiant tokius reikalus dalyvauja interesų grupès (pagal H. Zeigler 1993), kurių motyvacija dažniausiai yra ekonominè, 
bet dažnai yra ir politinè. Lukiškių aikštès atveju būtent taip ir yra. Be interesų grupių susitarimo bet kokie profesiniai veiksmai neturi prasmès (visada bus nepatenkintu ir demagogų). Susitarimo išraiška - nutarimas, ịstatymas, memorandumas ir t. t. Interesų grupių susitarimas turi apimti ir žiniasklaidą. L. Balcerovičius (Balcerowicz 1998) „nušvietimo efektą" apibūdina kaip mechanizmą, kuris gali teikti klaidingą informaciją apie naudingumo funkcijas ir todèl gali lemti netikusius sprendimus.

LR Seimo 1999 m. vasario 11 d. nutarimas Nr. VIII - 1070 Dèl valstybès sostinèje esančios Lukiškiu aikštès funkcijų leidžia pradèti konkrečius veiksmus, bet egzistuoja reali problema: kas vykdys šį nutarimą? Vykdytojo rangas turètų būti aukštesnis negu savivaldybė, kuri pasižymi ypač neskaidria veikla miesto plètros klausimais. Didžiulè klaida nutarimo vykdymą susieti su Vilniaus miesto politikais, bet būtent taip ìvyko. Tokios svarbos nutarimo vykdymo ir neeilinio objekto realizavimo negalima patikèti savivaldybès rango politikams ne tik dèl neskaidrios veiklos (vienas iš vertinimo komisijos nariu areštuotas dèl kyšininkavimo), bet grynai dèl tokio rango biurokratinio aparato veiklos specifikos. V. Kavolis savo knygoje Kultürine psichologija (1995: 55) tokią situaciją apibūdina taip:

Biurokratas, o ypač šiuolaikinis biurokratas profesionalas, yra taip pasineręs i savo procedūras, ar, geriausiu atveju, $j$ begalines kuo didesnio biurokratinio aparato efektyvumo paieškas, kad pamiršta uždavinius, kuriems spresti tos procedūros buvo numatytos. O pirmiausia toks biurokratas nebemato tu visu galutiniu vertybiu, kuriomis reikètu sverti tiek jo procedūras, tiek ir bet kokio žmogaus tikslus, taip pat ir pati biurokrata, kaip tam tikra procedūrų rinkini naudojantį žmogų.

Akivaizdu, kad ir vyriausybės rango biurokratų veikla taip pat negarantuoja kokybiško rezultato. Biurokratams negalima suteikti vertinimo funkcijos, ypač jeigu vertinimas susijęs su pasaulèžiūros dalykais. Atitiktis procedūroms ir pasauležiūra yra ne tas pats.

Tokius dalykus turètų spręsti valstybinè komisija arba specialus paminklo statymo komitetas, turintis tam tikrus igaliojimus ir finansavimą bei specialų darbo reglamentą. Pasak V. Kavolio, kürybiniai menai turèty paklusti kultūrinei sistemai (1995: 60).

\section{Lukiškių aikštès urbanistinės plètros etapai}

Iki Antrojo pasaulinio karo Lukiškių aikštėje buvo turgus, realizuotas pagal $1860 \mathrm{~m}$. Lukiškių turgaviečių planą, kuris labiau primena funkcinio zonavimo sche- mą (zonavimas pagal prekių rūšis - šienas, malkos ir pan.).

Realus urbanistinis procesas prasidejo XIX a. pradžioje, kai buvo numatytas iš principo naujas stačiakampis gatvių tinklas. Akivaizdu, kad tai yra kvartalinio morfotipo pradžia. Labai aiškiai apibrèžiamos būsimosios Lukiškių aikštės kontūrai pagal principą - tarp gatvių yra kvartalai, o ten, kur nèra kvartalo, yra aikštė (1 pav.).

1939 m. Lukiškių aikštėje uždrausta prekiauti ir pradèti rengti aikštės sutvarkymo projektai. Nuo $1950 \mathrm{~m}$. vyko daug konkursų dèl Vilniaus miesto centrinès dalies urbanistinès plètros ir Lukiškių aikštės suformavimo.

1953 m. Lukiškių aikšteje buvo pastatytas paminklas komunistų vadui V. Leninui. 1967 m. ir 1968 m. organizuoti konkursai, kurių tikslas nustatyti Lukiškių aikštès ir gretimybių urbanizavimo galimybes (nuo $1953 \mathrm{~m}$. iki 1991 m. aikštè vadinosi V. Lenino aikštè).

1972-1979 m. atlikti Vilniaus miesto centrinès dalies suplanavimo projektai, kuriuose architektai ir urbanistai sprendè naujų objektų ir susisiekimo sistemos miesto centrineje dalyje klausimus.

1991 m. paminklas V. Leninui demontuotas, tačiau aikštės suplanavimas iki šiol liko toks pats. Iš esmės pasikeitus socialiniam ir politiniam kontekstui, prasidejo diskusijų ir ginčų etapas, kuris tęsiasi iki dabar. Nors organizuojami įvairūs architektūrinių objektų (šalia Lukiškių aikštès ir prieigose) konkursai, kūrybinių dirbtuvių seminarai, mokinių rašinių konkursai, paskelbta daug politinių pareiškimų, lozungų ir dar daugiau demagogijos, realaus poslinkio bendroje Lukiškių aikštes koncepcijoje nèra. Pagrindiniai Lukiškių aikštes urbanistinès plètros etapai:

XX a. pradžia - Lukiškès - Vilniaus priemiestis. Ryški dominantè - Šv. Jokūbo ir Pilypo bažnyčia. Aikštės, kaip erdvès tipo, neįmanoma identifikuoti, nes teritorija labai mažai urbanizuota.

$\mathrm{XX}$ a.5-asis dešimtmetis - Vilniaus priemiesčių (tarp jų ir Lukiškių aikštes aplinka) urbanizavimo etapas, t. y. priemiestis virsta elementariu miesto rajonu. Tai matoma iš pokario architektų urbanistų darbų (A. K. Barutčev, J. O. Rubančik, I. N. Sobolev, A. I. Gegello, A. P. Velikanov, N. P. Šemolov, V. Mikučianis ir kt.). Nominali erdvė Lukiškių aikštė suvokiama kaip meninès kūrybos objektas. Kuriama unikali aikštės erdvinė urbanistinė koncepcija. Daugelyje tokių koncepcijų respektuojama urbanistinè ir kompozicinė ašis (šiaurè - pietūs), (Šešelgis 1997). Aiškiai išreikšta urbanistine ašis yra universalus urbanistinis meninis principas (2 pav.). 


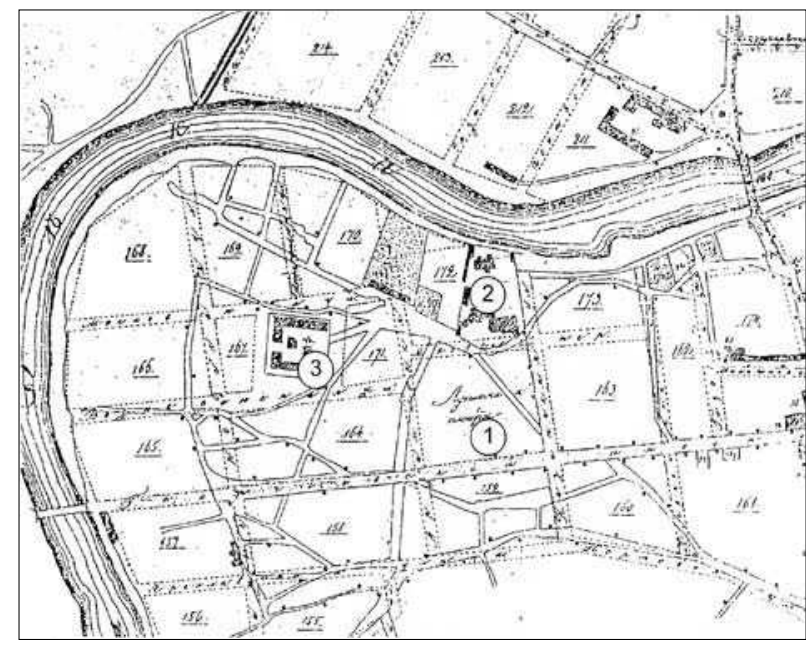

1 pav. XIX a. pradžios Vilniaus plano fragmentas: 1 - Lukiškių aikšte; 2 - Šv. Jokūbo ir Pilypo bažnyčios ir Dominikonų vienuolyno kompleksas; 3 - kalejjimas (punktyru pažymètas planuojamų gatviu tinklas)

Fig. 1. Fragment of Vilnius Plan at the beginning of the 19th century: 1 - Lukiškès Square; 2 - complex of St. Jacob's and St. Philip's Church and Dominican Monastery;

3 - prison (dotted line marks the network of streets)

Kadangi Lukiškių aikštės urbanistinės koncepcijos pagrindiniai urbanistiniai principai nusistovejo, $\mathrm{XX}$ a. 6-7 dešimtmetyje prasidèjo aikštės formantų, t. y. išklotinių formavimo etapas. $1968 \mathrm{~m}$. j̇vko unikalaus architektūros objekto Lukiškiu aikšteje ir prieigose (LKP CK pastatas) architektūrinis konkursas. Aikštès šiaurinès išklotinès formavimas tuo metu buvo aktuali problema.

Individualūs autoriniai projektai, idejjos, eskizai, koncepcijos. Labiausiai žinomi architekto A. Nasvyčio projektai - vizijos, kuriose akcentuojama „meridianinë" ašis.

Paskutinis etapas - 1990 m. iki dabar. Pagrindinès Naujamiesčio urbanistinès erdvès - Lukiškių aikštės formavimas, kompozicijos tobulinimas. Toliau eksploatuojama „Tautos namų" idèja, įvyko architektūrinis konkursas, skirtas Jokūbo ligoninès komplekso rekonstrukcijos projektui parengti.

Lukiškių aikštès urbanistinès plètros etapų analizè parodè, kad aikštès kompozicinių ašių sistema (ypač išreikšta ašis Pamėnkalnis - Šv. Jokūbo ir Pilypo bažnyčia) yra logiška urbanistinès struktūros tobulinimo koncepcija. Ašinès kompozicijos atsisakymas yra susijęs su erdvès tipo, konfigūracijos, dydžio keitimu.

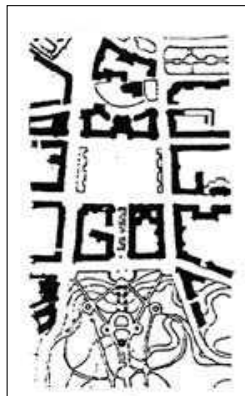

A

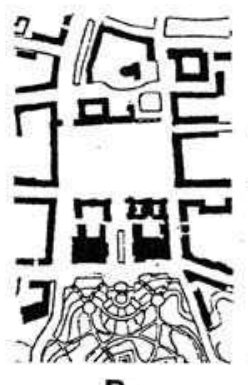

D

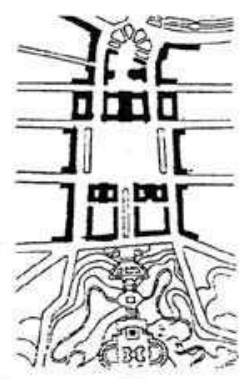

B

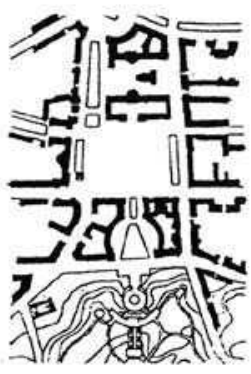

E

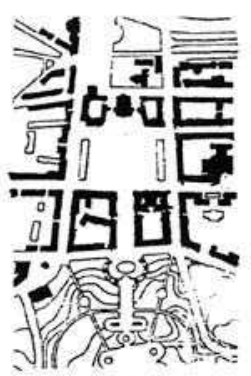

C

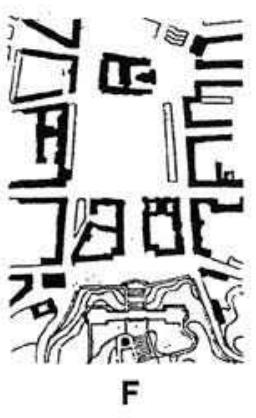

2 pav. Lukiškių aikštės planai 1945 m. Vilniaus miesto centro konkursiniuose projektuose Projektu autoriai: A - V. Mikučianis; B - A. P. Velikanov, N. P. Šelomov; C - I. N. Sobolev; D - V. Zubovas, K. Šešelgis; E - A. I. Gegello; F - A. K. Borutčev, J. O. Rubančik

Fig. 2. Layouts of Lukiškès Square in competitive urban projects for the centre of Vilnius, 1945.

Authors: A - V. Mikučianis; B - A. P. Velikanov, N. P. Šelomov; C - I. N. Sobolev; D - V. Zubovas, K. Šešelgis;

E - A. I. Gegello; F - A. K. Borutčev, J. O. Rubančik

\section{Lukiškių aikštės urbanistinė plètra atkūrus Nepriklausomybę (nuo 1990 m.)}

Atkūrus Nepriklausomybę (nuo 1990 m.) vyko keli architektūriniai konkursai, kurių sąlygos iš esmès skyrèsi. Konkurso sąlygos - socialinio užsakymo atspindys. İdomi problemos formulavimo metamorfozè, kuri akivaizdžiai matoma, palyginus ịvykusių konkursų sąlygas. Nors konkursų vyko daug ir įvairių, mus domina atkūrus Nepriklausomybę ìvykę konkursai, nes anksčiau įvykusiuose architektūriniuose konkursuose sprendžiami kitokie uždaviniai.

1995 m. organizuotas Lukiškių aikštės sutvarkymo konkursas turejjo vykti dviem etapais. Pirmojo etapo uždavinys - suformuoti Lukiškių aikštès paskirtí, nuspręsti, kokias ji galètų turèti funkcijas: reprezentacinę, memorialinę ar rekreacinę. Labai aiški ir konkreti užduotis. Šiame etape konkurse dalyvavo architektai ir urbanistai. Kadangi buvo sprendžiami principiniai klausimai, „grynojo meno“ atstovai (dailininkai, skulptoriai) nedalyvavo. 

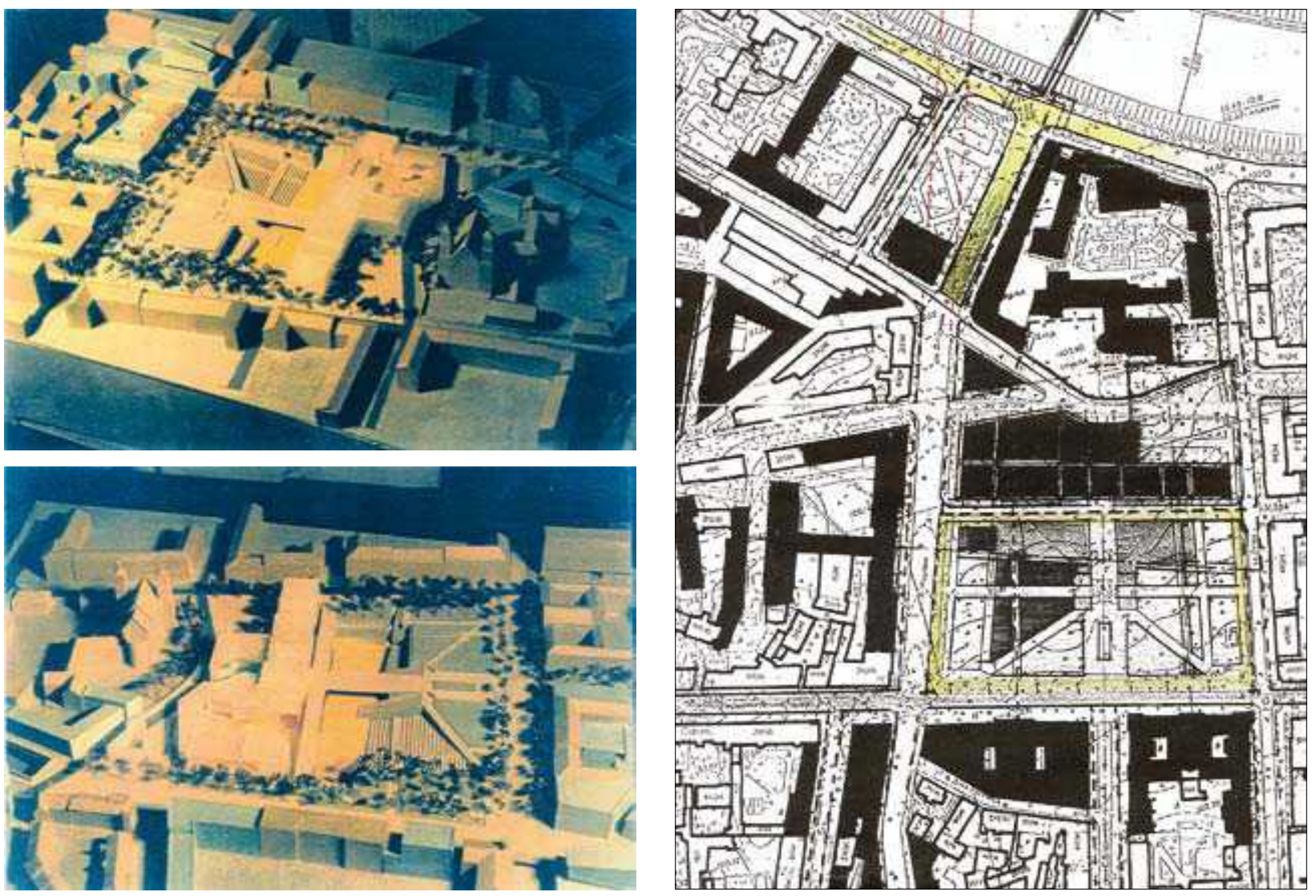

3 pav. Lukiškių aikštės sutvarkymo konkursas, $1995 \mathrm{~m}$.

Architektai: A. Vyšniūnas, A. Černiauskas, A. Sasnauskas, E. Neniškis, S. Kedys, V. Saveikis

Fig. 3. Lukiškès Square architectural competition, 1995.

Architects: A. Vyšniūnas, A. Černiauskas, A. Sasnauskas, E. Neniškis, S. Kedys, V. Saveikis

Išrinkti septyni geriausi architektūriniai projektai, kurie buvo susiję su iš principo visiškai skirtingomis traktuotèmis. Buvo nagrinèjami net variantai, iš esmès keičiantys aikštės fizinius parametrus, t. y. pačioje aikštèje buvo siūloma statyti pastatus (3 pav.). Antrajame etape numatyta suteikti aikštei naują urbanistinę kokybę, îprasminti mūsų šalies ir miesto istoriją, rekonstruoti ją, atsižvelgiant ị šiu dienų realijas, istorines, urbanistines ir menines galimybes. Tačiau antrasis konkurso etapas neįvyko.

1997 m. organizuotas aikštės laikinojo sutvarkymo konkursas, kurio tikslas - tik aikštès sutvarkymas, nekuriant memorialinio akcento. Dar niekad per visą Lukiškių aikštės istoriją konkurso sąlygos nebuvo tokios primityviai konkrečios, t. y. formuluojamas eilinis ūkinis uždavinèlis (Lukiškių aikštės ... 1998). Bendrą situaciją, problemos supratimą charakterizuoja tuometinio Lietuvos Architektų sajungos pirmininko K. Pempès raštas LR Seimui (Lietuvos architektų ... 1999):
Laikinasis aikštès sutvarkymas - kietu dangu irengimas ir taku perplanavimas - tai tiesiog pirmasis aikštès tvarkymo etapas, būdas jau šiandien iš sostines centro pašalinti „raudonaji purvyną". Jo igyvendinimas ne tik netrukdytu toliau nuosekliai rengti ir igyvendinti galutini aikštès sutvarkymo projekta, bet ir padètu išnaikinti Lenino aurą, kuri, praèjus jau beveik dešimčiai Nepriklausomybès metu, vis dar tebetvyro Vilniaus centre.

Vèliau šios idejjos atsisakyta. Lukiškių aikštės urbanistinès plètros klausimai atidèti neribotam laikui.

2008 m. paskelbtas Lukiškių aikštės sutvarkymo ir simbolio „Laisvë“ projekto sukūrimo konkursas (Lukiškių aikštės suplanavimo ... 2006). Formaliai uždavinys yra dvejopas - urbanistinis ir meninis, bet realus rezultatas terra tik abstraktus akcentas (kalbama apie I turo rezultatus). Būtent, viso labo tik abstraktus meninis akcentas, labai skambiai pavadintas „Laisvé“, nes neaišku, kodèl Lukiškių aikštejje iškasta duobè arba paprasčiausias stulpas aikštės kampe vadinamas simboliu „Laisvë“ (4 pav.). 


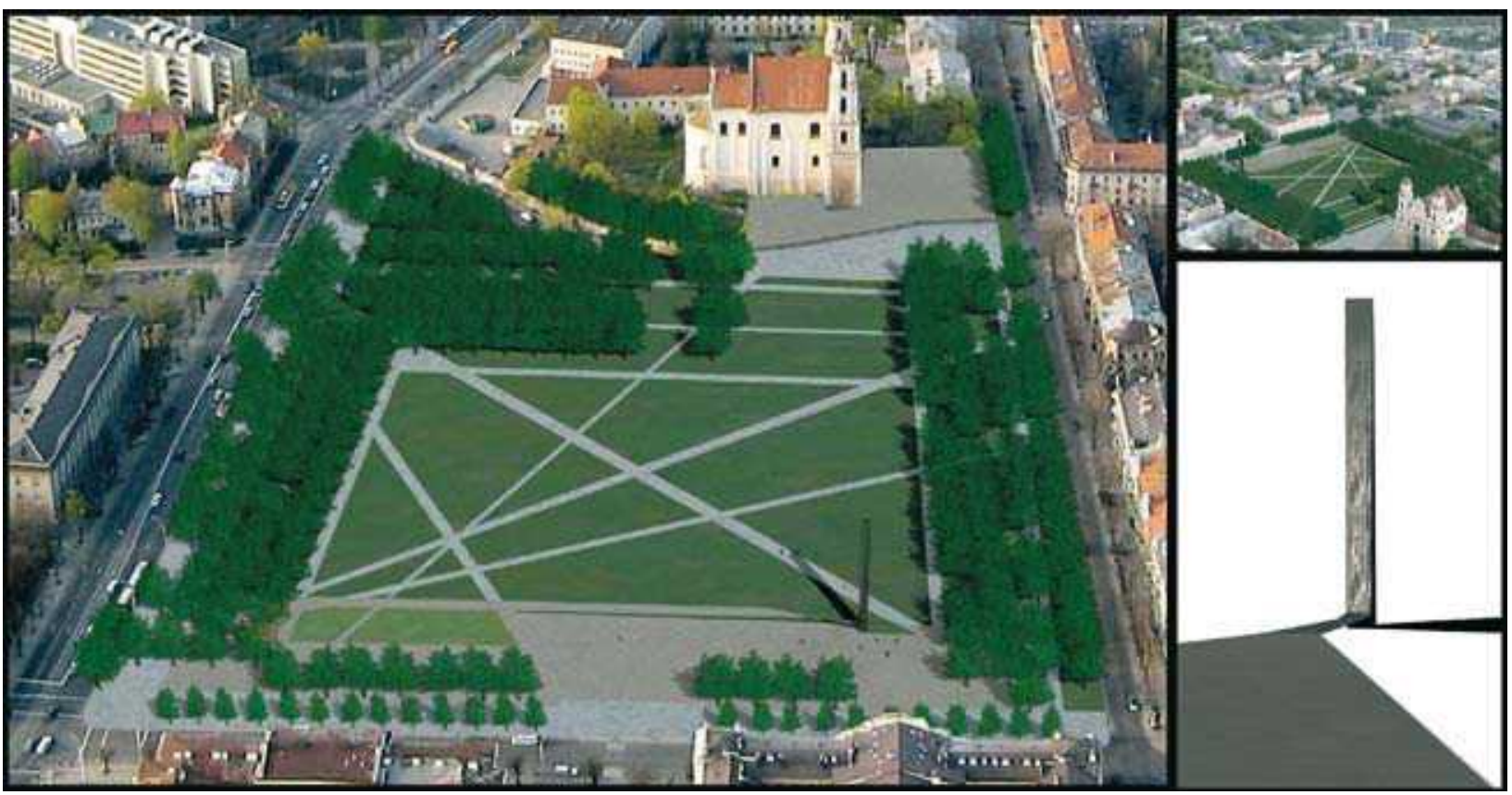

4 pav. Lukiškių aikštès sutvarkymo ir simbolio „Laisvè“ projekto sukūrimo konkursas 2008 m. Vienas iš septynių nugalètoju projektu. Tipiškas urbanistinio konteksto ignoravimo ir simbolio nekonkretumo pavyzdys

Fig. 4. Architectural competition for Lukiškès Square and symbol "Freedom", 2008.

One of the competition winners. Typical example of ignoring urban context and obscurity of symbol

Tiesiogiai nuo komunizmo nukenteję tremtiniai ir politiniai kaliniai užduotį formuluoja labai konkrečiai Lukiškiu aikštè turètų tapti memorialine reprezentacine erdve su įspūdinga menine plastika (skulptūromis), sukurta Laisvés kovu tema (Lietuvos politinių kalinių ir tremtinių sąungos raštas 1999-01-25 Nr. 357 p). Konkurso pavadinime nurodytas konkurso objektas - simbolio „Laisvë“ architektūrinis meninis projektas. Kartu reikia pastebèti, kad sąlygų punkte 7.1 vartojamas terminas šiuolaikinis memorialinis akcentas - kompozicija „Laisvë", atspindinti Lietuvos žmoniu kovas už laisve ir pergalę. Iš to kyla strateginis klausimas - kodèl taip komplikuotai suformuluota užduotis? Kodèl ne paminklas Laisvès kovų dalyviams, o simbolis, kuriame galbūt (o gal ir ne) atsispindès žmonių kovos už laisvę ir pergalę?

Nors kyla didelių itarimų dèl politinès destrukcijos ir sabotažo (negi atvirai prieštarausi paminklui Laivès kovotojams?), greičiausiai čia yra šeštojo ir septinto dešimtmečio avangardinès kultūros recidyvai. V. Kavolis savo straipsnyje „Socialinè avangardinių kultūrų psichologija" (1995: 138) tiksliai identifikuoja būdingiausius tokios logikos bruožus - ištrẻmimas iš istorijos (arba susvetimèjimas jai), kurioje ịvykę ar tebevykstantys ivykiai nebèra suvokiami kaip prasmingi ar emociškai reikšmingi; emocijos ir reikšmès atskyrimas.
Pasak V. Kavolio, bendraji sociopsichologinị modeli gali identifikuoti du pagrindiniai jo elementai: žmogaus atitrūkimas nuo istorijos, nuo kitu žmoniu, nuo kalbos, emocijos atsiejimas nuo prasmès, veiksmo nuo tikslo, nuo padariniu ir nuo „savęs paties“" (kuris tampa nebereikalingas) bei substancijų išgaravimas (kur tiek veiksmas, tiek atoveiksmis tampa negalimas) (1995: 139).

Bet esminis dalykas šiame konkurse - aikštè, kaip urbanistinis elementas, liko antrame plane.

\section{Juridinis aspektas}

Lietuvos Respublikos Seimas savo 1999 m. vasario $11 \mathrm{~d}$. nutarimo Nr. VIII - 1070 Dél valstybès sostinejje esančios Lukiškiu aikštés funkciju pirmuoju straipsniu patvirtino, kad Lukiškiu aikštè Vilniuje formuojama kaip pagrindinè reprezentaciné Lietuvos valstybès aikštè su Laisves kovu memorialiniais akcentais.

Antruoju straipsniu patvirtino, kad Lukiškiu aikštè Vilniuje, kaip istoriškai susiformavusi vientisa urbanistine erdvé, turi atlikti valstybine reprezentacine ir kartu visuomenine funkcija. Projektiniai sprendiniai turi apimti ir suderinti šias abi funkcijas - icomponuoti pastata Gedimino pr. 40 ir Auku gatvę bei įvertinti Pamėnkalnio (Taurakalnio) urbanistiniu sprendimu perspektyva. 
Šio nutarimo trečiasis straipsnis numatè, kas ir kaip privalo nutarimą vykdyti.

$2000 \mathrm{~m}$. spalio $17 \mathrm{~d}$. LR Seimas prièmè įstatymą Dèl Lukiškiu aikštès Vilniuje, pavedè aikštès reikalus tvarkyti Vyriausybei, tačiau Prezidentas V. Adamkus istatymą vetavo, motyvuodamas tuo, kad ístatyme reglamentuoti klausimai neturètų būti ịstatymu reglamentuojamas dalykas, o šiuos klausimus turètų spręsti Vilniaus miesto savivaldybė, atsižvelgdama ị Seimo pareikštą nuomonę. Taip sostinès reprezentacinės valstybinès aikštès statusas, Prezidento nuomone, buvo prilygintas eilinei, savivaldybès žinioje esančiai miesto aikštei, skverui ar gatvei.

Tai buvo lūžio taškas bendroje Lukiškių aikštès plètros ideologijoje ir koncepcijoje. Problemos algoritmą (fundamentiniai problemos aspektai, politinis ir socialinis užsakymas, profesinė veikla, reprezentacija, dizainas) galima iliustruoti schema (5 pav.).

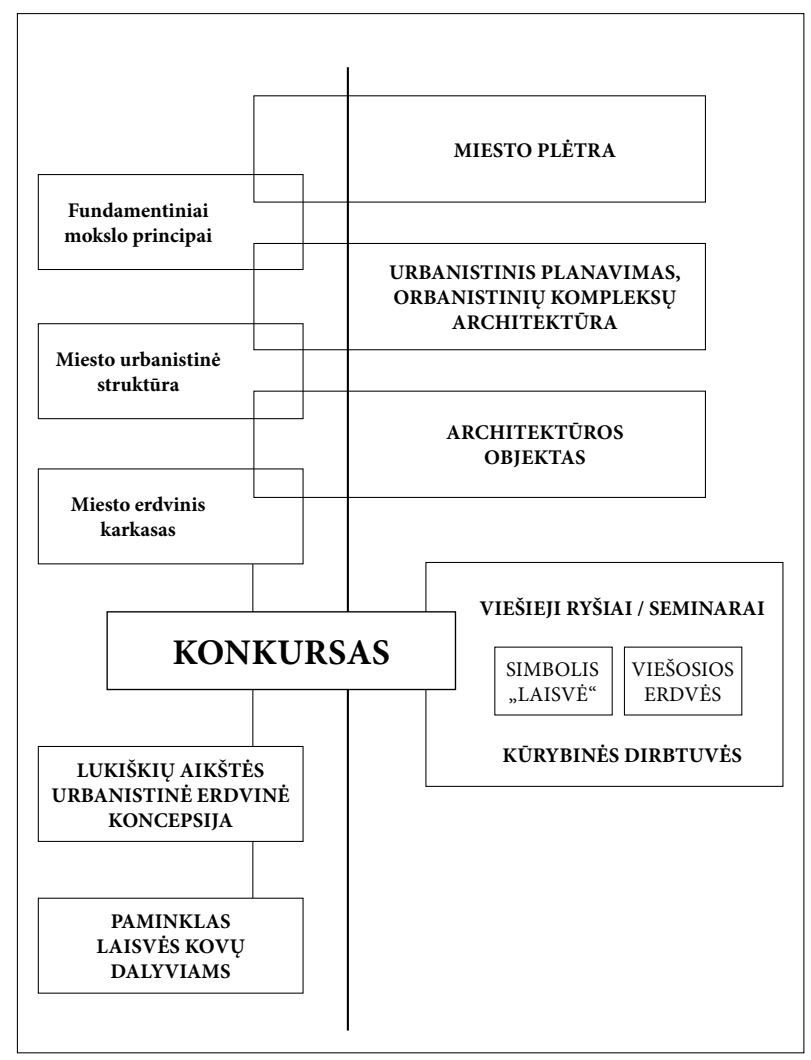

5 pav. Problemos algoritmas. Fundamentiniai problemos aspektai, politinis ir socialinis užsakymas, profesinè veikla, reprezentacija, dizainas

Fig. 5. Problem algorithm. Fundamental aspects of the problem, social and political order, professional practice, representation, design

\section{Lukiškių aikštė - urbanistinès struktūros elementas. Meniniai urbanistikos principai}

Vilniaus miesto centrinès dalies kompozicinis karkasas pasižymi tuo, kad labai aiškiai išreikšta Gedimino prospekto ašis ir skersinė Lukiškių aikštès ašis (ašis Profsajungų rūmai - architektūrinè kalva dešiniajame Neries krante). Daugelyje Lukiškių aikštės projektų, koncepcijų tai i̇vertinta, bet vienuose projektuose vizualinè kompozicinè ašis sutapatinama su fizine ašimi, t. y. bandoma paversti fiziniu traktu, kituose tai tèra vizualinis ryšys.

Nors kai kurie architektai labai skeptiškai vertina pokario Lukiškių aikštès urbanistinius projektus dèl pernelyg aiškiai išreikštos ašinès kompozicijos, bet reikia pripažinti, kad tai yra neišvengiama dèl dirbtinai primestos ir nuolat eskaluojamos „Tautos namų“ idèjos ir jau realizuotos architektūrinès kalvos dešiniajame Neries krante.

Architekto A. Nasvyčio pasiūlytoje Vilniaus centro silueto ir pagrindinių aukštybinių akcentų sistemoje (6 pav.) kompozicinių ašių sistema yra tiesiog užprogramuota. Šioje schemoje matyti, kad neatsakingai elgiantis iškyla pavojus pagrindiniam miesto struktūros branduoliui - Gedimino piliai, nors pačiai nominaliai Lukiškių erdvei itakos tai neturi. İvertinus architekto A. Nasvyčio grupès konkursini projektą, akivaizdu, kad tai yra nuoseklus ir logiškas urbanistinių idèjų realizavimas, ịvertinant susiklosčiusią situaciją.

Kartas nuo karto kyla diskusija dèl aikštès raudonųjų linijų ir kompozicinių ašių. $2007 \mathrm{~m}$. vasarị remiantis kūrybinèmis dirbtuvemis parengti Vilniaus centrinès dalies viešujų erdviu ir prieigu prie Lukiškiu aikštes pasiūlymai, kurie Vilniaus savivaldybès iniciatyva išleisti

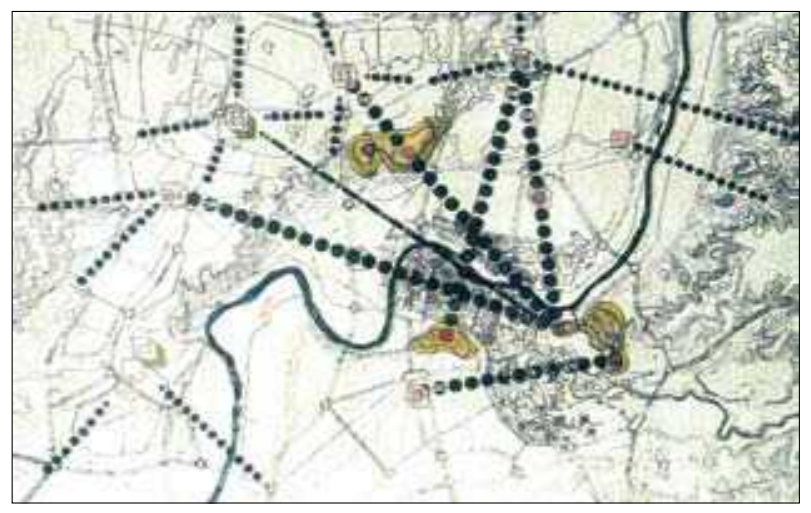

6 pav. Vilniaus centro silueto ir pagrindinių aukštybinių akcentu sprendiniai. Architektas A. Nasvytis, 1974 m. Fig. 6. Proposals of Vilnius silhouette and skyscraper system. Architect A. Nasvytis, 1974 
atskiru leidiniu. Atkreipè dèmesị architekto T. Grunskio

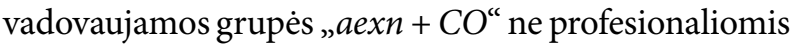
priemonėmis (brèžiniais, maketais, vizualizacijomis), bet piktogramomis ir raštiškai pateikti Lukiškių aikštès formavimo principai:

Šiandien esantis aikštès ašinès kompozicijos sprendinyss (ir pačioje aikštèje, ir atsižvalgiant j urbanistini konteksta) atitinka to meto tarybinę ideologiją, kai aikštes erdvè buvo monofunkcé ir jos erdvinè kompozicija buvo skirta ideologiniam vadui sakralizuoti. Naujas erdves kompozicijos sprendinys turètų aiškiai (radikaliai) skirtis nuo ankstesniojo. Siūlome atsisakyti ašinès kompozicijos, kaip erdvés formavimo principo, ir pačioje aikštèje, ir jos prieigose.

Polifunkcijos principu naujai atsirandantis monumentas (ar monumentai) taptu lokaliu akcentu jam skirtoje erdvejje. Atsisakius ašinès kompozicijos, kaip erdvès formavimo principo, monumento dislokacija taip pat neturètu büti centruota visos erdvés atžvilgiu (Vilniaus centrinès ... 2007)

Grupès „aexn + CO“ architektas T. Grunskis teoriniuose darbuose, o ypač straipsnyje Diktato architektūra. Lukiškiu aikštè (2007), pagrindè savo idèjas, be to, kūrybinių dirbtuvių pradžioje surengtame specialiame seminare kai kurie grupès nariai perskaitė pranešimus, ir galų gale tie patys nariai recenzavo Lukiškių aikštès konkursinius projektus. Todèl tai daugiau priminè savos pasaulèžiūros ir atitinkamai urbanistinès kompozicijos sampratos propagavimą, o ne objektyvų konkursinių projektų ịvertinimą. Tokia veikla turi visus viešujų ryšių veiklos požymius.

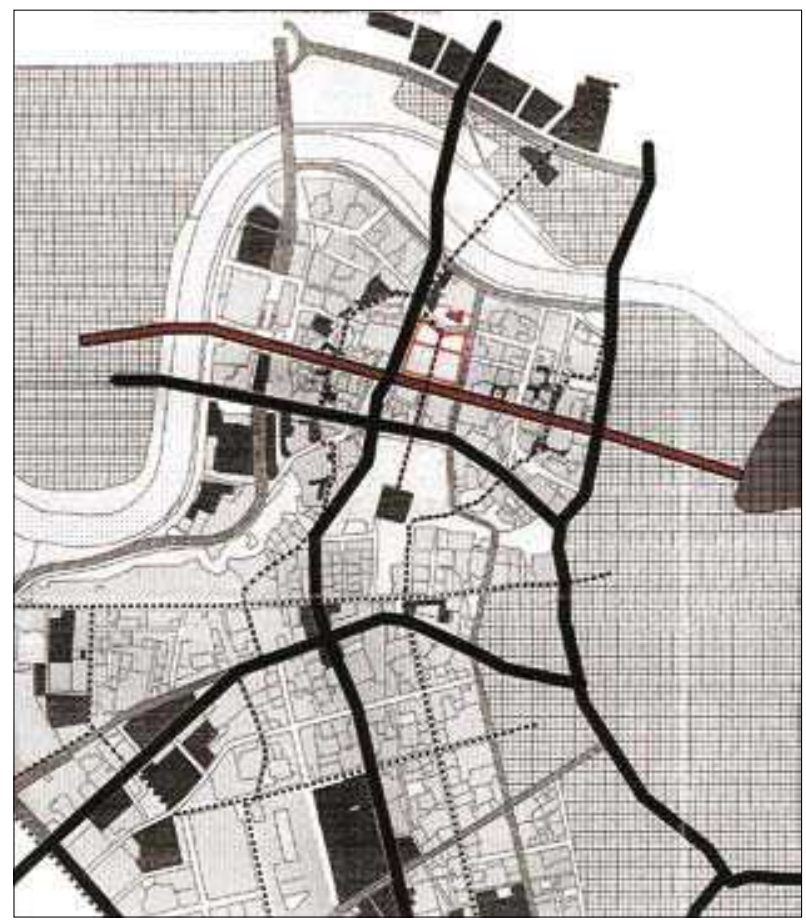

7 pav. Vilniaus miesto Naujamiesčio detaliojo plano esamos padèties analize ir rajono raidos programa. Sl „Vilniaus planas", $1998 \mathrm{~m}$.

Fig. 7. Analysis of the present detailed plan and urban development program of Naujamiestis district in Vilnius. Municipal company "Vilniaus planas", 1998

Vilniaus miesto Naujamiesčio rajono raidos programoje (temos vadovas prof. dr. Z. J. Daunora), (Vilniaus miesto ... 2000) labai aiškiai apibrěžiamos būsimosios Lukiškių aikštès kontūrai pagal principą - tarp gatvių yra kvartalai, o ten, kur nèra kvartalo, yra aikštè (7 pav.).
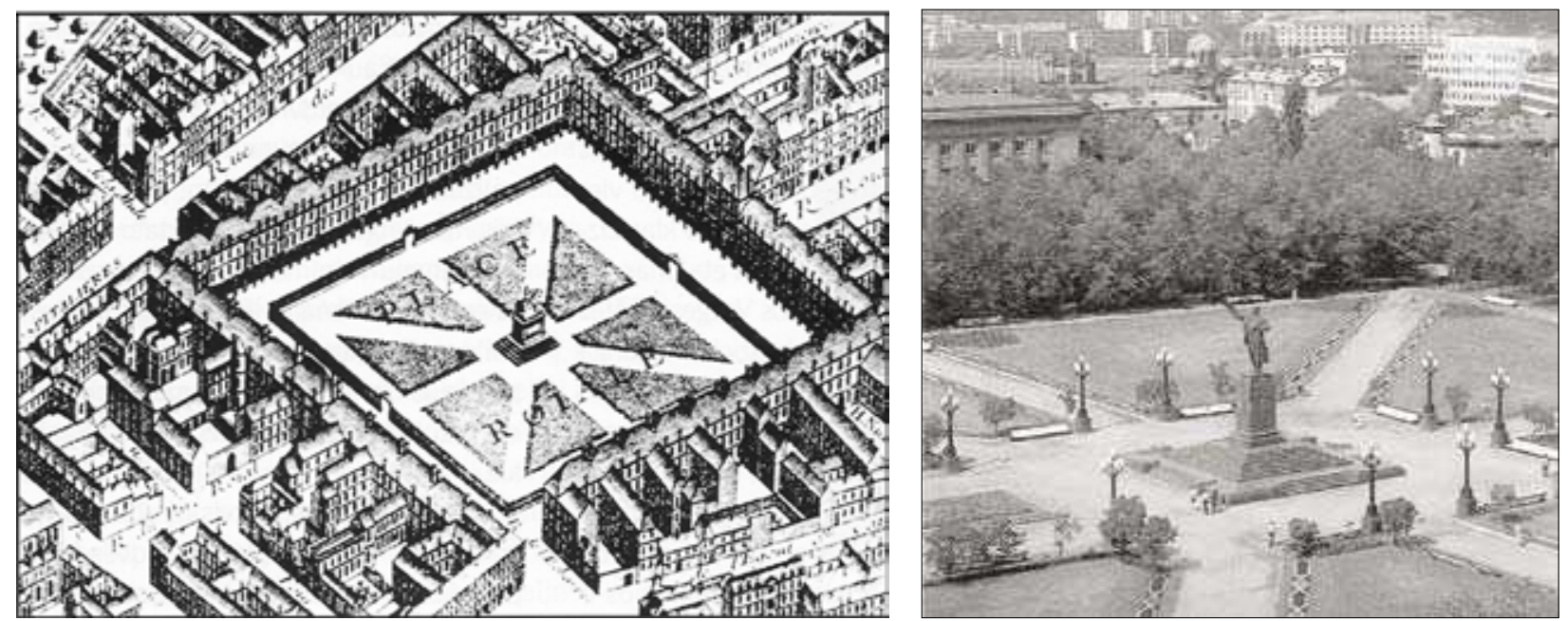

8 pav. Ištrauka iš T. Grunskio straipsnio „Diktato architektūra. Lukiškių aikštė” (2007)

Fig. 8. Extract from T. Grunskis' article "The dictate architecture. Lukiškès Square" (2007) 


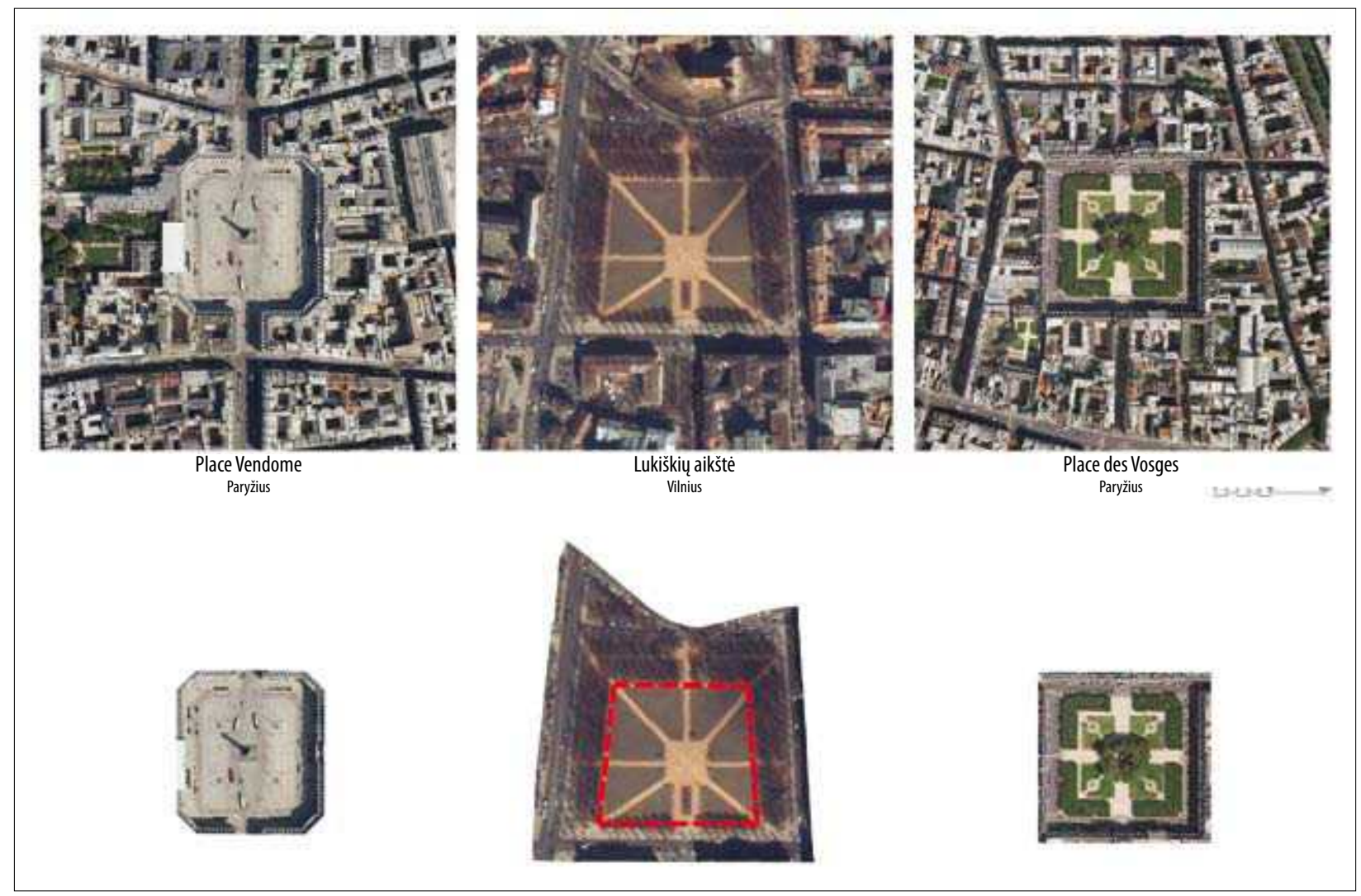

9 pav. Vandomu, Vogezu aikščių Paryžiuje palyginimas su Lukiškių aikšte Vilniuje pagal aikštės vietą urbanistinejje struktūroje (aikštès fizinio dydžio kriterijus)

Fig. 9. Square size comparison of Lukiškès Square in Vilnius with de Vosges and Vandome Squares in Paris

Todèl keistai atrodo kai kurių teoretikų pastangos lyginti Lukiškių aikštès matmenis tarp medžių eilių aikštès vidinëje pusėje su Vogezų aikštès Paryžiuje matmenimis tarp aikštės išklotinių. Tai rodo, kad egzistuoja principinis neaiškumas dèl Lukiškių aikštès matmenų, t. y. „raudonųjų linijų" Objektyvus kriterijus - aikštès vieta ir dydis - urbanistinèje struktūroje dažnai painiojamas su paprasčiausia takų sistema (8, 9 pav.). Paminklas geometriniame aikštès centre traktuojamas kaip labai didelis minusas. Vogezų aikštės Paryžiuje ir Lukiškių aikštés Vilniuje tapatumas nustatytas pagal paminklo komponavimą geometriniame centre ir radialinę takų sistemą, nors fiziniai dydžiai plane nèra identiški (Grunskis 2007).

Tokio tipo aikščių, t. y. uždaras kontūras, kvadratinè konfigūracija plane, paminklas geometriniame centre ir panašus dydis, galima surasti ir daugiau - Plaza Mayor Madride su paminklu Pilypui III (1617 m., architektas Juan Gomez de Mora), Amalienborg rūmų aikštė Kopenhagoje (1760 m., architektas N. Eigtved) su paminklu karaliui Frederikui V, Vandomų aikštė Paryžiuje (1699-1701 m., architektas Ž. A. Mansar) su kolona- paminklu Napoleonui I, pastatytai vietoj skulptoriaus F. Žirardon skulptūros, dedikuotos karaliui Liudvikui IV ir pan.

1990 m. Vilniaus technikos universiteto (dabar VGTU) Urbanistikos katedra atliko Vilniaus Žvèryno rajono urbanistinę analizę (1993). Ypač įdomūs prof. dr. Z. J. Daunoros atlikti Žvèryno rajono erdvinès ir plano struktūros savitumų tyrimai bei jų respektavimo galimybès (Daunora 1993). Išorinių vizualinių ryšių metodu ištyrus Žvėryno ir Naujamiesčio rajonų kompozicinị vaidmenị bendramiestinëje struktūroje, matyti, kad urbanistiniai kompleksai, esantys Neries upés slènyje (t. y. miesto centrinès dalies apatineje terasoje), yra apžvelgiami iš rajonus supančių Neries šlaitų viršutinių altitudžių, iškilusių virš nagrinëjamų teritorijų nuo 30 iki 80 metrų (10 pav.).

Šiame kontekste Lukiškių aikštė yra sudètinè struktūros dalis. Ivertinus Pamėnkalnị ir ant jo stovinčius Profsajungų rūmus bei dešiniajame Neries upès krante realizuotą ",architektūrinę kalvą" (Europos aikštès architektūrinis urbanistinis kompleksas) panoraminiame lygyje susiformavo aktyvus vizualinis ryšys, kuris turetų 


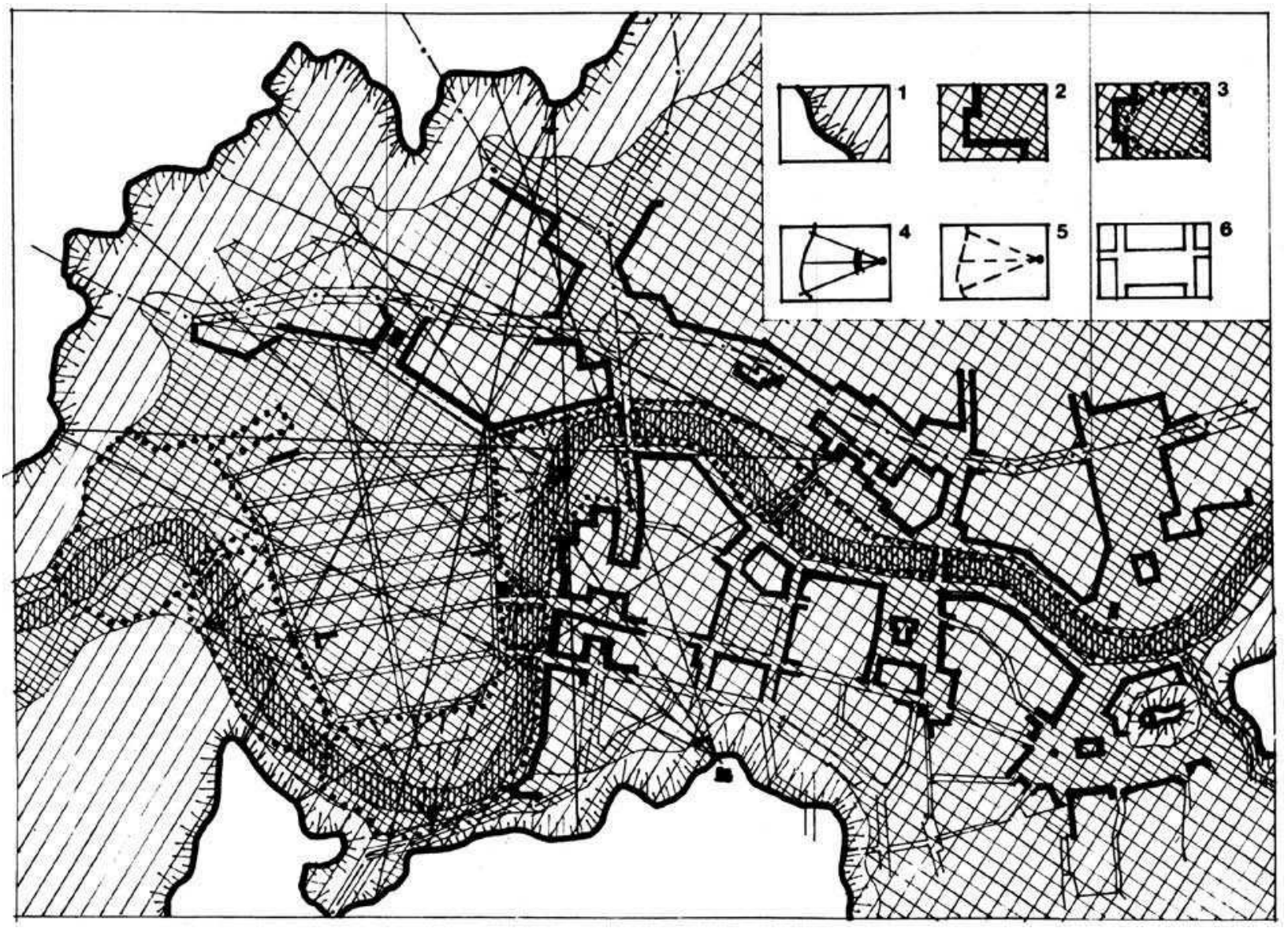

10 pav. Žvėryno ir Naujamiesčio vizualinių erdvių ir ryšių struktūra. Vizualinès erdvès. Prof. dr. Z. J. Daunora, 1990 m.:

1, 2, 3 - bendramiestinio, rajoninio ir lokalaus lygio svarbesni vizualiniai ryšiai: 4 - panoraminiai; 5 - žemi masinio stebejjimo; 6 - gatvès ir aikštès

Fig. 10. Structure of visual spaces and links of Žvèrynas and Naujamiestis districts in Vilnius. Visual spaces. Prof Dr Z. J. Daunora, 1990.1, 2, 3 - essential urban, regional and local visual links: 4 - panoramic, 5 - low mass observation; 6 - streets and squares

būti respektuojamas žemosios terasos lygyje, t. y. Lukiškių aikštès lygyje.

Lukiškių aikštės ir jos aplinkos kompozicinių ašių sistema smulkiai išnagrinèta kituose VGTU Urbanistikos katedros mokslo darbuose.

1997 m. Vilniaus miesto savivaldybès Architektūros ir statybos departamento (dabar Miesto plètros departamentas) užsakymu VGTU Urbanistikos katedros mokslininkai atliko Vilniaus Lukiškių aikštès ir aplinkos urbanistinius tyrimus (temos vadovas - prof. dr. Z. J. Daunora), (Lukiškių aikštės ... 1997), kurie buvo pateikti kaip 1997 m. laikinojo aikštès sutvarkymo konkurso sąlygų priedas (11 pav.). Verta pacituoti kai kurias šio darbo išvadas:

Kultūrologinio diskurso aspektu, pasikeitus Lukiškiu aikštès socialinès tvarkos ir globaliosios miesto idejos lemiamam semantiniam erdves tipui, jis tradiciškai turètu kisti, atsižvelgiant tiek $\dot{i}$ sociokultūrinio erdves prototipo poreikį, tiek į konkrečius miesto bendruomenès interesus. Sprendinys turètų respektuoti tradicinę urbanistinio tinklo raidą ir ilgaamžiškumo kriterijus, neprogramuojant semantinio, struktürinio, kompozicinio ar idèjinio konflikto ateičiai.

Mokslo darbai urbanistikos srityje, pokario urbanistiniai projektai, konkursiniai projektai po 1990 metų parodè, kad ašinès kompozicijos principas, kaip erdvès formavimo principas yra fundamentalus, nepriklausomas nuo ideologijos. Reikia aiškiai skirti ašinès kompozicijos principą Lukiškių aikštès prieigose (tai traktuotina daugiau kaip vizualinis ryšys panoraminiame lygyje) ir centristinę ašinę paminklo kompoziciją - paminklas aikštės geometriniame centre aikštės parteryje (Daunora 1998).

Pagal sovietinių laikų ideologinius kanonus sukonstruota aikštė (su paminklu vadui), be abejo, negali būti tvarkoma remiantis tokiais pat principais, todèl aikštes 

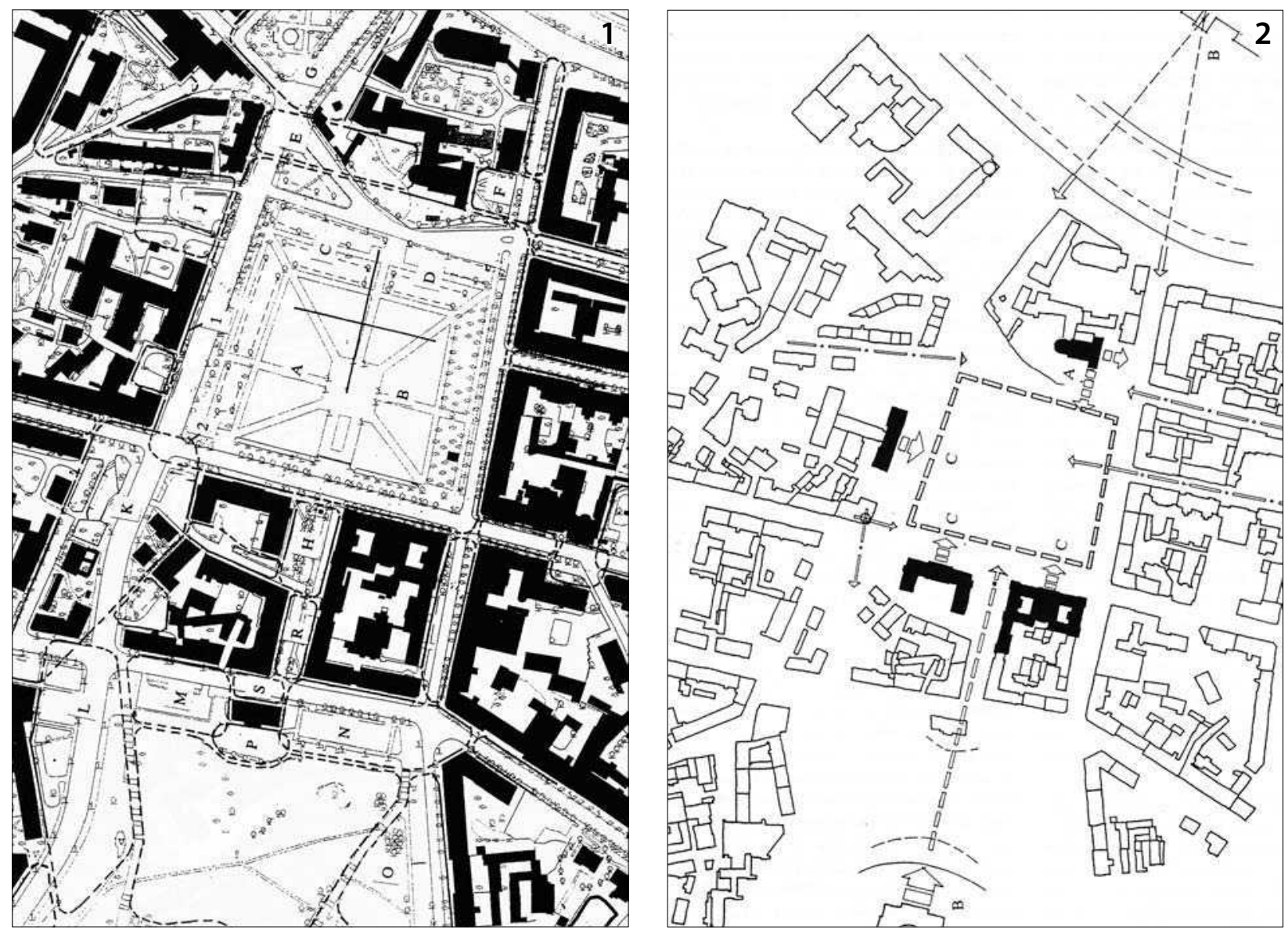

11 pav. Lukiškių aikštės ir aplinkos urbanistiniai tyrimai. VGTU Urbanistikos katedra, 1997 m.: 1 - Lukiškiu aikštės aplinkos kvartalinis morfotipas, erdvinis karkasas; 2 - Lukiškių aikštès aplinkos kompozicinių ašių schema

Fig. 11. Urban investigation of Lukiškès Square and its environment. Vilnius Gediminas Technical University, Dept of Urban Design, 1997: 1 - planning and spatial principles of Lukiškès Square and its environment; 2 - scheme of compositional axes of Lukiškès Square and its environment

geometrinio centro akcentavimo principas nèra privalomas, bet negali būti ignoruojami laiko patikrinti urbanistikos meno meniniai principai.

\section{Lukiškių aikštė - viešoji erdvė ir viešųjų ryšių objektas}

2003-02-18 dienraštyje Lietuvos žinios Nr. 40 (10469) buvo paskelbtas i̇domus straipsnis Seimūnas taiso Vilniaus veidą. Straipsnis įdomus visai ne profesine prasme, bet dèl precedento - pirmą kartą viešai, naudodamas žiniasklaidos priemones "projektuoti miestą" pradèjo politikas:

Seimo vicepirmininkas Vytenis Andriukaitis siūlo Vilniuje, ant Tauro kalno esančius Profsajungos rūmus paversti Tautos namais, kuriuose galettu vykti ES valstybiu Vadovų ir ministrų posèdžiai. Gedimino prospektas, kuriame koncentruojasi visos svarbiausios valstybines institucijos, turètu virsti valstybès ašimi su tai išreiškiančiais aiškiais architektūriniais akcentais.

Dar viena tokia ašis galètu driektis nuo Tauro kalno, apimdama Lukiškiu aikštę, Nacionalinę vaizduojamojo meno galeriją, būsimaji savivaldybès pastata ir dar tik planuojama Europos įstaigu centrą.

Ko gero, tai buvo miesto urbanistinès plètros procese „viešųjų ryšių“ užuomazga. Dabar šis procesas yra tiek patobulejęs, kad viešųjų ryšiu specialistai, komentuotojai, moderatoriai, interpretuotojai netgi jaučiasi pranašesni už specialistus.

2007-02-02 Vilniaus m. Rotušèje vyko kūrybinių dirbtuvių seminaras, kurio tikslas suformuluotas labai pragmatiškai - prieš prasidedant kūrybinèms dirbtuvèms architektūros ir istorijos ekspertai pristatys Europos aikščiu ir viešujų erdviu formavimo patirtị bei naujoves. Seminaro klausytojams pranešimus skambiais pavadinimais skaitè „ekspertai“, kurie terminus aikštè ir viešoji 

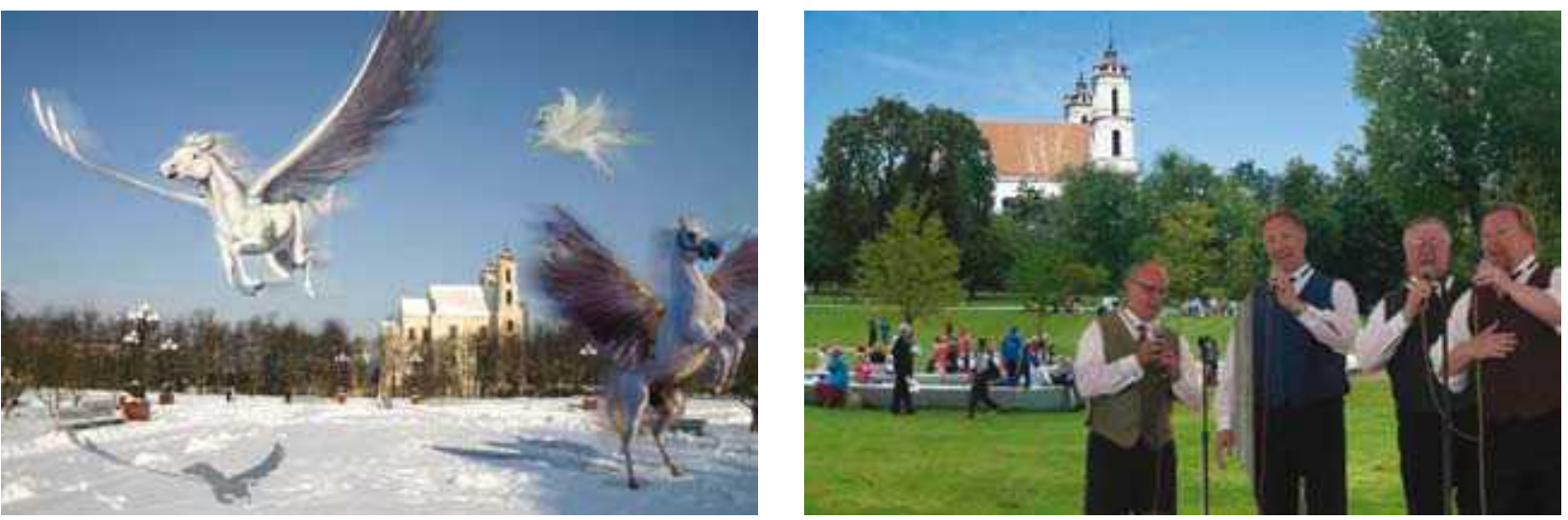

12 pav. Internetinės apklausos rezultatai, pateikti vizualizacijose (www.lukiskiuaikste.lt)

Fig. 12. Examples of Internet Poll results

erdve vartojo labai laisvai, traktuodami juos kaip visiškai tapačius dalykus. Be to, didelis „,emocionaliai pakrautų“ terminų kiekis rodo, kad daugiausiai pranešimus skaitè ne profesionalai, bet paprasčiausi interpretuotojai. Elementarūs viešosios erdvès pavyzdžiai apibūdinami labai sudètingomis sentencijomis - Konfliktiška aplinkos ir ǐženklinimo sandūra; Laiko pojūčio aktualizavimas kaip erdves perkūrimo ir atminties palaikymo priemone; Kasdienybès poetika pagristas aikštès meninis sprendimas; Aikštes kūrimas "transplantuojant" vaizdinius; Memorialines, reprezentacines ir rekreacines funkcijos hibridizacija; Vaizdiniu abstrahavimas; Funkcijos ir fikcijos dermé. Tokia situacija rodo bendrą architektūros teorijos Lietuvoje būklę, kurią galima apibūdinti daugiau kaip literatūrinę veiklą negu kaip argumentuotą profesinę kritiką.

Vakarų Europoje situacija yra kitokia. Pvz., Aldo Aymonino ir Valerio Paolo Mosco savo knygoje Contemporary Public Space. Un - Volumetric Architecture (Skira Editoje S. p. A.; Milano 2006), (Aymonino, Paolo Mosco, 2006) komentuoja visiškai kitas erdvinio formavimo priemones ir profesinius instrumentus (paviršius, vertikalè, kevalas, figūros, žemės grafika, technologijos, ivykis ir pan.), apsieidami be hipertrofuoto eilinio daikto "poetizavimo“.

2008-02-12 Vilniaus m. Rotušèje vyko kūrybinių dirbtuvių seminaro rezultatų apibendrinimas. Kaip ir reikejjo tikètis, kokybiško rezultato nebuvo. Architektai tikèjosi dalyvauti rimtesniame architektūriniame konkurse, kuriame numatytas solidus piniginis prizas laimètojui, todèl niekas net nebandè rodyti kokybiškas profesionalias idejjas.

Tai, kad Vilniaus m. Rotušèje vykęs nesèkmingas kūrybinių dirbtuvių seminaras nebuvo šiaip renginèlis, rodo visa savivaldybès finansuojamų renginių sistema - kūrybinių dirbtuvių seminaras, kūrybinès dirbtuvès, kūrybinių dirbtuvių rezultatų aptarimas, internetinès anoniminès apklausos (gauti 102 atsakymai), mokinių rašinių konkursas (4 500 rašinių) ir pan. Tai, be abejo, profesionaliai parengta viešųjų ryšių sistema, neturinti jokio ryšio su valstybinès reikšmės aikšte.

Idomus viešųjų ryšių renginys - internetinè apklausa, kurios rezultatus grafiškai pateikè savivaldybės nusamdyti anoniminiai vizualizatoriai. Tokiais rezultatais nę̇manoma tikèti vien dèl labai neskaidraus apklausos organizavimo ir dèl atsakymo „koregavimo“, t. y. internetiniam tekstui suteikiama vizuali forma. Internetiniame puslapyje www.lukiskiuaikste.lt atvirai abejojama LR Seimo nutarimo pagrịstumu, kuris atseit „apriboja diskusijų lauką ", o tai reiškia ne ką kitą, kaip atvirą prieštaravimą idejai ịprasminti Laisvès kovas:

Vasario 2-12 d. Vilniaus savivaldybe organizavo kürybines dirbtuves, laukdama menininku ir miestiečiu pasiūlymu dèl Lukiškių aikštès rekonstrukcijos. Tačiau diskusiju laukas buvo apribotas 1999 m. Seimo nutarimo „Dèl valstybès sostinèje esančios Lukiškiu aikštès funkcijü“, kuris ịtraukè memorialinę bei reprezentacinę aikštès paskirtis“. <...> Kadangi šioje apžvalgoje nurodeme tik bendriausias 102 išsakytu nuomoniu gaires - detaliau apklaustu žmoniu idèjas prašome žiūréti pristatomose vizualizacijose. Šios apklausos dalyviai išties pateike viziju ir sprendimu įvairovę, galinčia stipriai praplesti tolesnę politinę bei architektūrinę diskusija apie Lukiškiu aikštés ateiț. Todèl projekto organizatoriai nuoširdžiai dèkoja visiems, skyrusiems laiko ir dèmesio apsilankyti puslapyje www.lukiskiuaikste.lt ir išsamiai atsakyti i pateiktus klausimus. Ši apklausa, be abejo, nepretenduoja i jokị objektyvu mokslo tyrima, nes ji buvo atliekama nesiremiant jokiais griežtesniais sociologinių apklausu metodais. Tai buvo improvizuotas projek- 
tas, siekiantis per kelias kürybinèms dirbtuvèms skirtas dienas įtraukti kuo įvairesniu nuomoniu i vykstančiq diskusiją apie šia svarbia viešaja miesto erdvę.

Tokios veiklos rezultatas - urbanistinès struktūros elementas aikštè, kaip erdvès tipas, virsta įvairių atsitiktinių funkcijų kratiniu, o paminklas Laisvès kovų tema visiškai nebeaktualus (12 pav.).

Kad ir kaip ten būtų, akivaizdu, kad pokario Lietuvos Laivès kovos nèra nacijos bendrumo pagrindas.

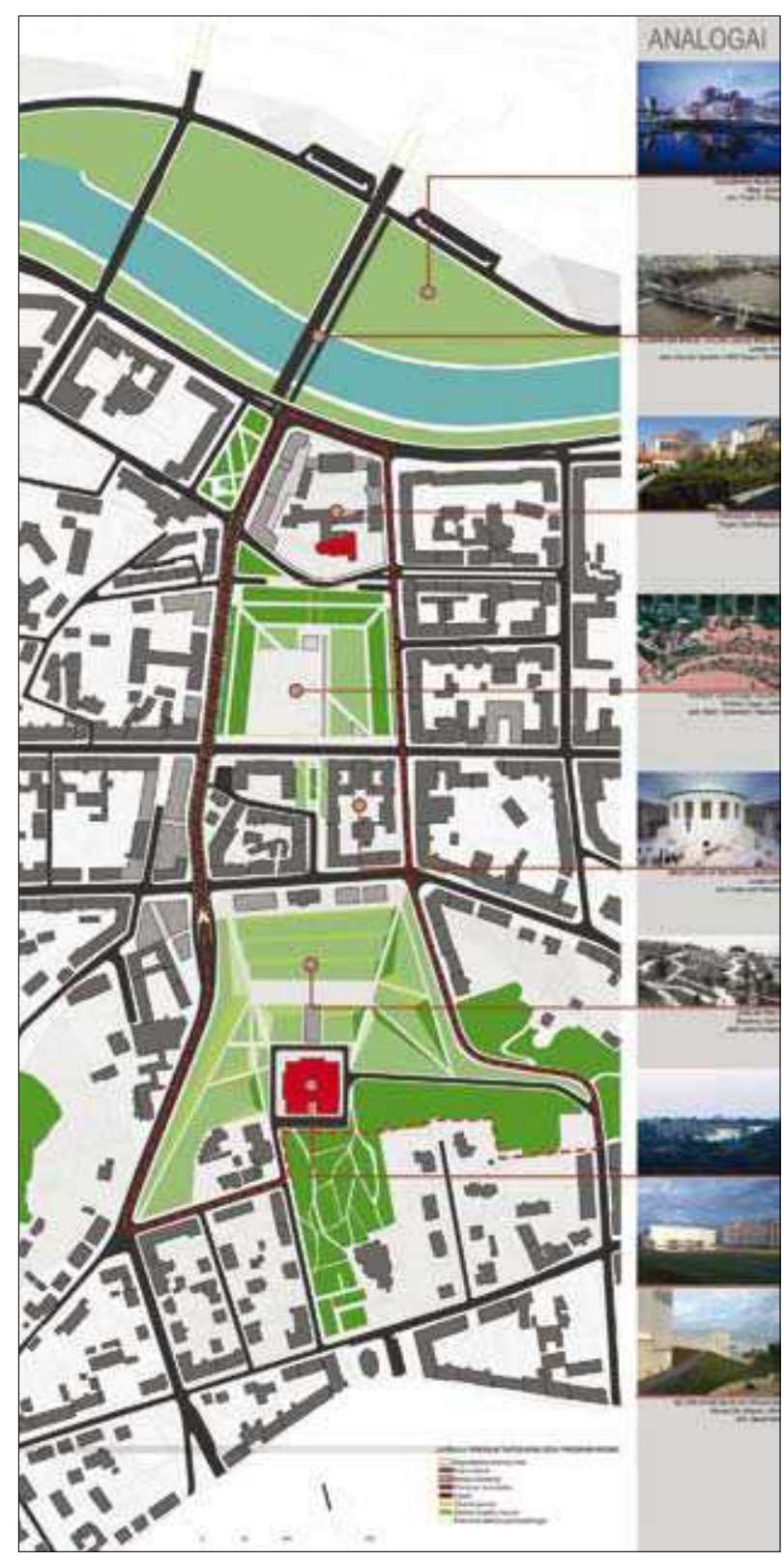

13 pav. Teritorijų, lemiančių Lukiškių aikštès sprendinius, programos vizija

Fig. 13. Urban development program of territories near Lukiškès Square
Geriausiu atveju dar galima susitarti dèl kunigaikščių Mindaugo, Gedimino, Vytauto, XX a. pradžios kultūros veikèjų V. Kudirkos, J. Basanavičiaus, bet dèl pokario Laivès gynėjų atminimo įamžinimo konsensusas vargiai i̇manomas. Tai yra faktas. Neveltui sociologai vis labiau pradeda domettis šiuo reiškiniu - skeptišku indiferentišku požiūriu i vieną iš kruviniausių Lietuvos istorijos periodų.

\section{Lukiškių aikštės sutvarkymo ir simbolio „Laisvè“ projekto sukūrimo konkursas}

2008 m. ịvyko Lukiškių aikštès sutvarkymo ir simbolio „Laisvë“ projekto sukūrimo konkursas. Išrinkti septyni geriausi projektai. VGTU Urbanistikos katedros Urbanistinès analizės mokslo laboratorijos specialistai taip pat dalyvavo konkurse (Lukiškių aikštès suplanavimo... 2008). Straipsnio autoriaus nuomone, tikslinga pateikti konkursinio projekto pagrindinius teiginius.

\section{Sprendiniai artimiausiose teritorijose, lemiantys Lukiškių aikštès sprendimą. Aikštès funkciniai ir vizualiniai ryšiai su jais}

Teritorijų, lemiančių Lukiškių aikštės sprendinius, programos vizija (pagal konkurso sąlygų III skyriaus 16.8 punktą) yra bendra Naujamiesčio žemutinès terasos urbanistinès plètros problema, kurią kokybiškai išspręsti ịmanoma rengiant atskirą urbanistinị Naujamiesčio rajono konkursą/galimybių studiją. Lukiškių aikštes suplanavimo konkursiniame projekte įmanoma pateikti tik bendrus šių teritorijų tvarkymo principus (13 pav.).

Organizuojama transporto judèjimo sistema, prioritetą teikiant pėstiesiems, želdynams, viešosioms erdvėms. Siūloma pastatyti požeminę V. Kudirkos gatvę. Požeminès gatvės pradžia - ties Jasinskio g., gatvės pabaiga - ties Lvovo g. (po Neries upe arba rekonstruojant Baltąji tiltą, paverčiant jị ne tik pesčiųjų tiltu, bet ir transportiniu). Antžeminis gatvių tinklas lieka toks pats, tik jame „nuramintas“ eismas. Svarbiausiuose mazguose požeminė gatvė jungiasi su antžeminiu gatvès tinklu.

Buvę Profsąjungų rūmai, Pamėnkalnis („Tautos namü“teritorija). Ši teritorija yra didelių diskusijų objektas vien dẻl emociškai angažuotų terminų, pvz., „Tautos namai“, vartojimo. Kad ir kaip ten būtų, kultūrinès paskirties objektas (pvz., universalios paskirties koncertų salè) vietoj buvusių Profsąjungų rūmų iš principo yra įmanomas. Svarbu tik kad naujas objektas miesto 


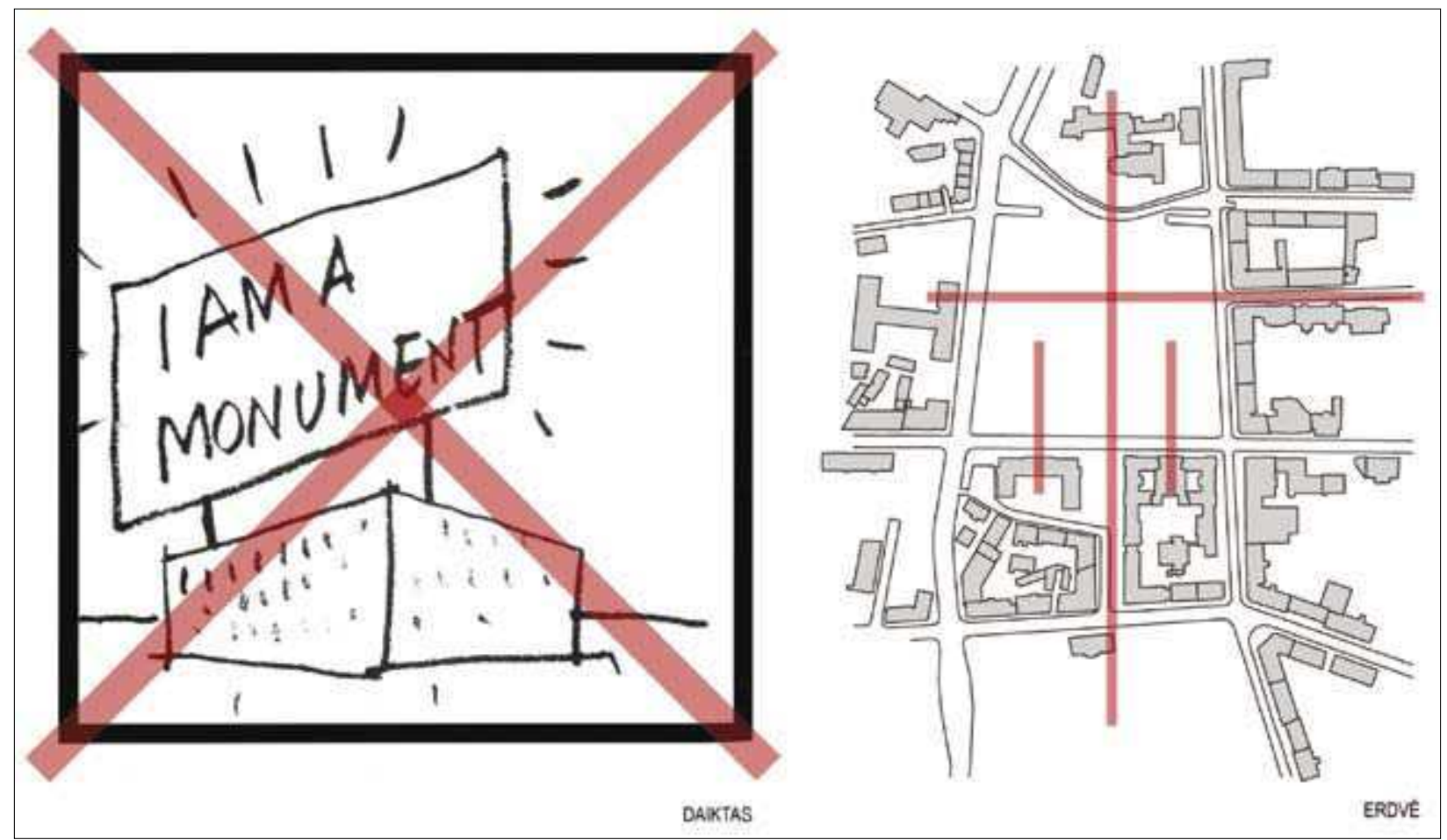

14 pav. Simbolio „Laisvė“ pagrindinè koncepcija išplaukia iš bendros erdvinės Lukiškių aikštės koncepcijos. Kūrybos objektas yra "erdvë", bet ne "daiktas-paminklas"

Fig. 14. The main conception of symbol "Freedom" is deduced from the spatial conception of Lukiškès Square.

The creation object is "space", but not a "thing/monument"

struktūroje ir panoramose nekonkuruotu su istoriniu Vilniaus miesto branduoliu - pilių kompleksu. Egzistuoja ryškus vizualinis ryšys su Lukiškiu aikšte, kurio visiškai nebūtina paversti fiziniu pèsčiųjų kanalu, t. y. tiltas virš Pamėnkalnio gatvès nenumatomas.

Aukų gatvè ir Genocido aukų muziejus prie Lietuvos gyventojų genocido ir rezistencijos tyrimų centro. Šiuo metu čia stovi Lapteviečių bendrijos pastatytas paminklas lietuviams, kentëjusiems ir žuvusiems Jakutijoje (skulpt. J. Jagèla, 2006 m.). Taip pat Auku gatvejje stovi 1988 metais iš lauko riedulių sumūrytas kuklus ženklas/ paminklas, ịprasminantis Laisvès kovotojų atminimą. Šio paminklo meninè vertè labai abejotina, bet tai yra ryškus istorinis ženklas. Todẻl siūlome šį istorinį ženklą apdengti stikliniu gaubtu.

Vilniaus Šv. Apaštalų Pilypo ir Jokūbo bažnyčios ir vienuolyno ansamblis. Konkursiniame projekte ịvertintas buvusios Šv. Jokūbo ligoninès teritorijos virtimas visuomenine komercine zona. Naujai formuojama visuomeninio komercinio komplekso pietinè išklotinè (nuo Lukiškių aikštės) esminio poveikio aikštės sprendiniams neturi.

Vašingtono aikštė ir naujas dešiniojo Neries kranto visuomeninis prekybinis centras. Atsisakius Krei- vojo tilto idejjos, išlieka Vašingtono aikštè, kaip žalia viešoji erdvè. Susisiekimas su dešiniojo Neries kranto visuomeniniu prekybiniu centru priklauso nuo V. Kudirkos/J. Tumo-Vaižganto gatvès rekonstrukcijos laipsnio. Tada galutinai taps aišku, koks yra Baltasis tiltas pésčiujų ar transporto.

Lukiškių aikštė yra prie dviejų ypač svarbių magistralių - V. Kudirkos/J. Tumo-Vaižganto ir Gedimino prospekto. Gedimino prospektas yra pagrindinè Naujamiesčio žemutinès terasos gatve, prie kurios istoriškai susikloste savita viešųjų erdvių sistema su labai aiškiai išreikštomis kompozicinèmis ašimis.

Viename Gedimino prospekto gale - Katedros aikštè (senoji istorinè dalis), kitame - Nepriklausomybès aikštė (LR Seimo pastatų kompleksas ir nacionalinė M. Mažvydo biblioteka). Taip pat yra Odminių skveras; V. Kudirkos skveras su naujai statomu paminklu V. Kudirkai; Žemaitès skveras, kuriame numatoma statyti A. Gudaičio paveikslų galeriją; Lukiškių aikštè su numatomu statyti simboliu „Laisve““.

Šioje viešųjų erdvių sistemoje Lukiškių aikštė yra pati svarbiausia viešoji erdvė, kurios fizinis dydis leidžia ją paversti pagrindine visos valstybès aikšte. 
Planuojamos Lukiškių aikštės sprendiniai suderinti su rekonstruojamo Gedimino prospekto sprendiniais, numatant galimybę prospekto dali tarp Vasario 16-osios ir J. Tumo-Vaižganto gatvių panaudoti įvairiems renginiams.

Egzistuoja mitas, kad Lukiškių aikštė yra per didelè. Lukiškių aikštès dydis miesto urbanistineje struktūroje (plane) yra objektyviai susiklostęs faktas, priklausantis nuo gatvių tinklo. Todèl aikštès architektūrinès kompozicijos tobulinimas yra nesusijęs su aikštės parametrų keitimu. Užstatyti aikštę arba jos dalị pastatais yra iš principo neteisingas kelias, nes aikštès fizinio dydžio mažinimas plane aikštę pavers paprasčiausiu skveru.

Pagal konkurso sąlygas reprezentacinèje ir memorialinėje Lukiškių aikštės dalyje numatoma organizuoti valstybines šventes bei kitus renginius, planuojant, kad galètų sutilpti apie 1,5 tūkst. žmonių.

Tai rodo, kad aikštè yra valstybinio rango, bet kartu ji yra daugiafunkcè. Aikštejje turi atsirasti vietos visoms miestui būdingoms funkcijoms ir paskirtims: kasdienei miestiečių veiklai, rekreacinei, visuomeninei, memorialinei reprezentacinei, bet aikštė neturi virsti lokalia apželdinta viešąja erdve su labai lokaliais dekoratyviniais akcentais.

Lukiškių aikštėje simboliniai kapai, koplyčios ir pan. nenumatomi.

Vientisoje erdveje funkcinis zonavimas yra labai sąlyginis dalykas, todèl siūlome aikštę zonuoti, įrengiant sieną Aukų gatvès ašies tęsinyje (ašis šiaurè - pietūs). Siena dalija aikštę į dvi dalis - rytinę ir vakarinę. Aikštès rytinejje dalyje numatoma memorialinè, ramaus poilsio zona, o vakarinëje dalyje numatoma ịrengti igilintą amfiteatrą, skirtą visuomeniniams ir valstybinès reikšmès renginiams.

Sienoje numatomi ịrengti vertikalūs funkciniai ryšiai - liftai, laiptinès iš požeminių aikštès lygių.

Požeminejje aikštės dalyje suplanuotos automobilių stovèjimo vietos, vieši tualetai, patalpos ir įrenginiai, reikalingi aikštės priežiūrai. Požeminiai lygiai numatomi altitudèse $+97,00$ ir $+94,00$. Išèjimai į aikštès paviršių organizuojami jau minètoje sienoje (liftai, laiptinès), taip pat numatomi atskiri vertikalūs ryšiai palei visą aikštės perimetrą, reaguojant ị susiklosčiusią taku sistemą.

Ašinès kompozicijos principas, kaip erdvès formavimo principas, yra fundamentalus, nepriklausomas nuo ideologijos. Reikia aiškiai skirti ašinès kompozicijos principą Lukiškių aikštès prieigose (tai traktuotina daugiau kaip vizualinis ryšys) ir centrišką ašinę paminklo kompoziciją - paminklas aikštès centre.

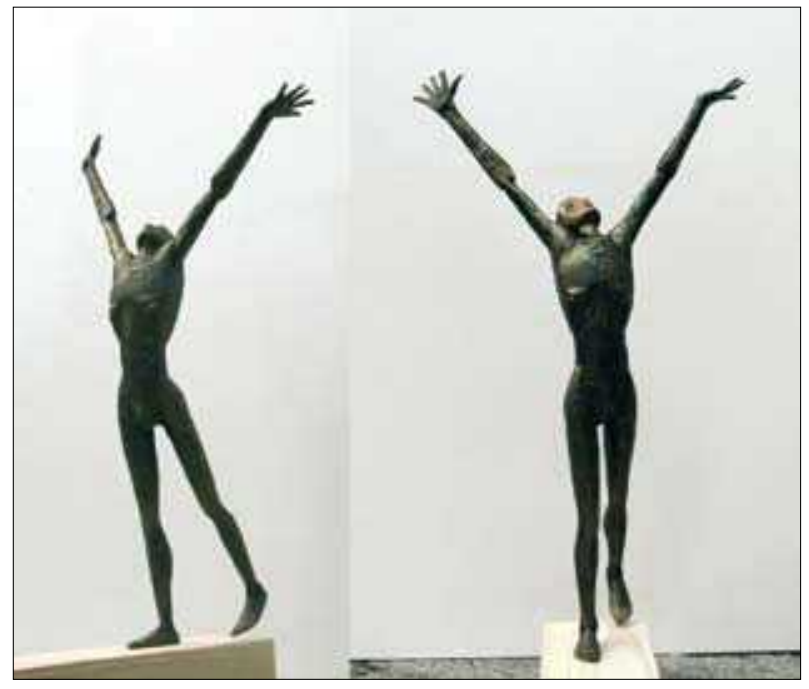

15 pav. Simbolio „Laisvè“ pagrindinè koncepcija - Laisvès troškimas

Fig. 15. The main conception of symbol "Freedom" is desire for Freedom

Pagrindinis aikštės akcentas - simbolis „Laisvë“ komponuojamas ilgojoje meridianineje ašyje „Tautos namai“ - Šv. apaštalų Pilypo ir Jokūbo bažnyčios ir vienuolyno kompleksas.

Konkurso pavadinime nurodytas konkurso objektas - simbolio „Laisvë“ architektūrinis meninis projektas. Kartu reikia pastebèti, kad sąlygų 7.1 punkte vartojamas terminas šiuolaikinis memorialinis akcentas - kompozicija „Laisvë“, atspindinti Lietuvos žmonių kovas už laisvę ir pergalę. Konkursiniam projekte siūlomas apibendrintas simbolis. Besiveržiančio ị laisvę žmogaus figūra simbolizuoja veržimąsi ị Tiesą, Šviesą, Laisvę.

Pagrindiniai simbolio „Laisvë“ konstravimo ir komponavimo principai:

- Simbolio „Laisvë“ pagrindinè koncepcija išplaukia iš bendros erdvinès Lukiškių aikštės koncepcijos. Kūrybos objektas yra „erdvë“, bet ne „daiktas-paminklas"(14 pav.).

- İvertinus aikštės dydị ir valstybinį rangą siūloma žmogaus figūra ( $6 \mathrm{~m}$ aukščio), nes dekoratyvinès meninès kompozicijos labiau tinka skverams.

- Daugiau kaip 2/3 egzistavimo laiko Lietuvos valstybė kovojo už savo valstybingumo išlikimą, už Laisvę. Todèl būtina akcentuoti nuolatinị Laisvès troškimą, akcentuoti veržimąsi ị Laisvę. Be laisvų žmonių nèra laisvos valstybės (15 pav.).

- Lukiškių aikštės architektūriniame urbanistiniame komplekse nesiūlomi tragiškos lemties, skaudaus pralaimejimo, liūdesio ir pan. ženklai, labiau būdin- 

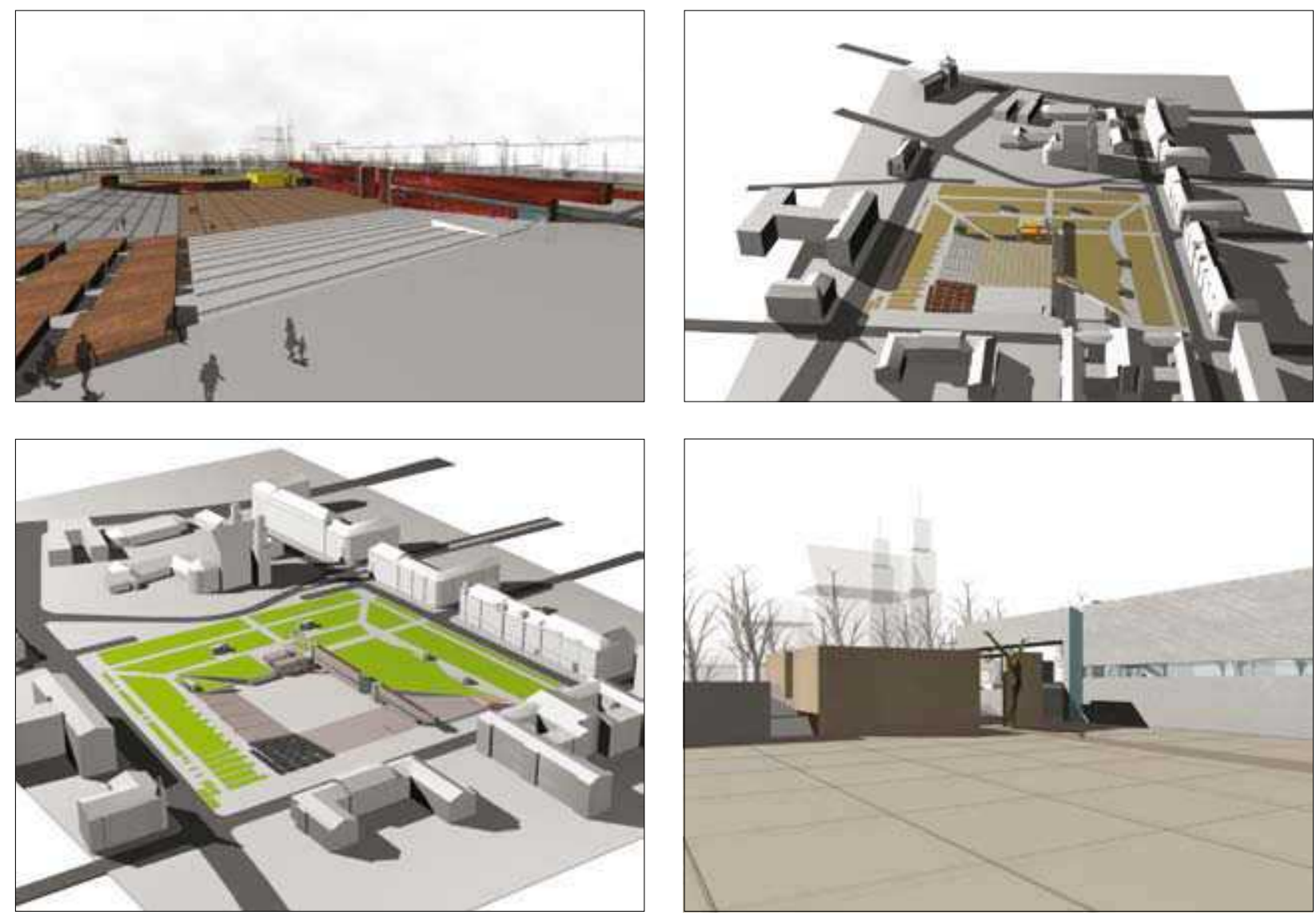

16 pav. Lukiškių aikštės architektūrinio urbanistinio komplekso vizualizacijos

Fig. 16. Visualizations of Lukiškès Square architectural and urban complex

gi karių kapams ar kitoms analogiškoms rimties zonoms, memorialams ir pan.

- Lukiškių aikštės architektūriniame urbanistiniame komplekse vengiama pompastiškumo, gigantomanijos, deklaratyvaus patriotizmo ir pan. (16, 17 pav.).

- Religiniai ar kiti reikalingi simboliai ir ženklai gali atsirasti kituose projekto detalizavimo etapuose, bet jie nebus dominuojantys.

- Besiveržiančio į Laisvę žmogaus figūra liejama iš bronzos. İ laisvę besiveržiančio žmogaus skulptūrinè figūra parodyta sąlygiškai.

\section{Išvados}

1.Prof. R. Grigo retorinis klausimas: kaip išugdyti civilizuota valstybingumo jausma, jeigu per šimtmečius lietuvis patyre tik ta valstybès forma, kuri buvo primesta svetimuju? - gali būti traktuojamas kaip pagrindinè ir neguodžianti išvada. Lukiškių aikštès istorija po 1990 m. - savigarbos neturejjimo istorija. Labai neatsakingas požiūris į valstybinių simbolių ir ženklų statymą. Grūto parko ir paminklo F. Zappai gerbèjų yra daugiau, negu paminklo Laisvès kovų dalyviams šalininkų.

2. Nacija, neturinti etnokultūrinès saviidentifikacijos problemų, dažniausiai turi svarbiausią valstybès vietą su visa tam tikslui skirta atributika ir simboliais. Pvz., Latvijos sostinejje Rygoje stovintis Laisvès paminklas (skulptorius K. Zale) niekam nekelia jokių abejonių. Analogiškai yra visoje Europoje. Tų šalių piliečiams tai kelia pasididžiavimą. Tai yra savaime suprantamas dalykas save gerbiančioje valstybèje. Lietuvoje tokios vietos nèra.

3.Pagrindinejje Lietuvos aikštejje neįmanoma apeiti klausimo apie paminklų statymą, svarbu, koks paminklo statusas - dekoratyvinis elementas eilinèje „viešojoje erdvèje“ ar skulptūrinè kompozicija, ịprasminanti valstybinès reikšmès ịvykị, veikejjus ir pan. pagrindinèje valstybės aikštèje. Tai yra susiję su aikštės statusu - valstybinès svarbos aikštė, skirta reprezentacijai, ar eilinè „viešoji erdvè“? Lukiškių aikštė Vilniuje negali būti traktuojama vien tik kaip savival- 


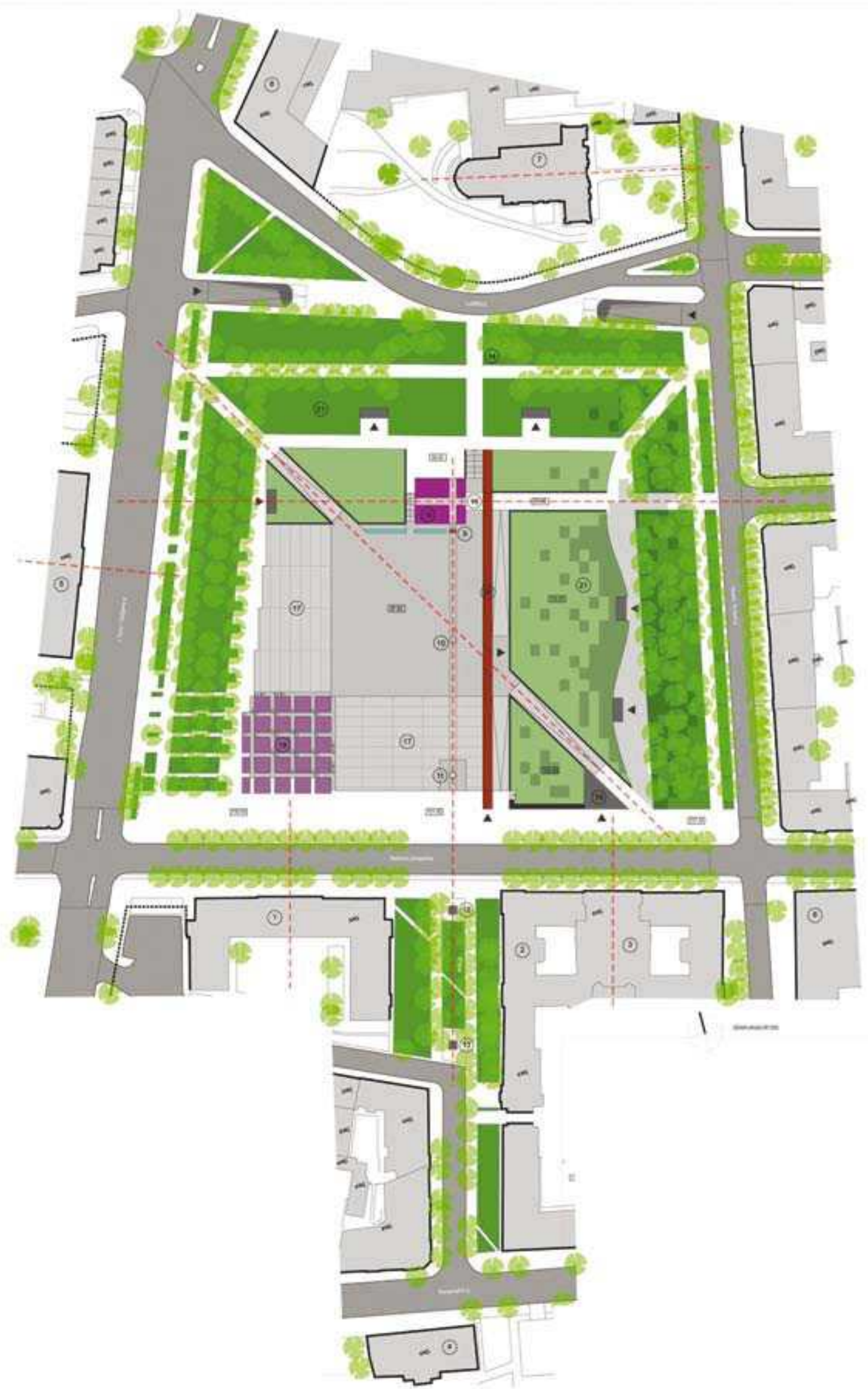

17 pav. Lukiškių aikštės architektūrinio urbanistinio komplekso pagrindinis brèžinys Fig. 17. Principal scheme of Lukiškès Square architectural and urban complex 
dybės rango viešoji erdvė, nes toks svarbus valstybès sostinès urbanistinès struktūros elementas turi žymiai didesnių galimybių.

4. Šiuo metu niekas neprieštarauja teiginiui (bent jau atvirai $\mathfrak{i}$ akis nesako), kad lietuvių tautos kovos už Laisvę ir Nepriklausomybę (ypač XX a. - prievartiné asimiliacija, deportacijos ir trèmimai, partizaninès kovos ir t. t.) buvo innirtingos ir pareikalavo daug aukų. Nèra ir atvirai prieštaraujančių paminklui ar monumentui, skirtam kovotojams už Laisvę ir Nepriklausomybę. Kyla įnirtingas pasipriešinimas, kai paminklas pasiūlomas Lukiškių aikštèje. Prisidengus rūpesčiu dèl didžiausios Vilniaus aikštès, faktiškai nepritariama konkretaus paminklo kūrimui, vietoj to siūlant nekonkretų simbolị. Motyvų ir argumentų daug ir ivvairių, bet juos lengva sugrupuoti:

- Teigiama, kad, pastačius paminklą Laisvės kovotojams Lukiškių aikštèje, tai bus „liūdesio“ aikštè. Taip buvo komentuojamas LR Seimo $1999 \mathrm{~m}$. vasario $11 \mathrm{~d}$. nutarimas Nr. VIII - 1070.

- Teigiama, kad pastačius paminklą Laisvès kovotojams Lukiškių aikštėje eiliniams miestiečiams nebeliks vietos. Todèl savivaldybės valdininkai pagal savo supratimą bandè paversti aktyvaus socialinio veiksmo aikšte - buvo pastatytas, o vèliau nugriautas statinys, panašus ị Triumfo arką.

- Teigiama, kad klasikinio Laisvès kovotojų paminklo samprata yra pasenusi. Todel reikia „naujų formu ir išraiškos priemonių“. Kaip kriterijai pateikiami pavyzdžiai, neturintys jokio ryšio su nagrinèjamu klausimu, su nacijos identitetu, ženklais ir pan.

5. Paminklo visos Lietuvos Laisvès kovų dalyviams nèra, tèra tik paminklai atskirų apygardų partizanams, kurie statomi pagal tam tikrą valstybinę programą. Idomi detalè - paminklai partizanų apygardoms statomi provincijoje, bet ne didžiųjų miestų aikštèse (paminklas Algimanto apygardos partizanams Troškūnuose, Prisikèlimo apygardos partizanams Šeduvoje, Vytauto apygardos partizanams Utenoje, Didžiosios kovos apygardos partizanams Gelvonuose, Žemaičiu apygardos partizanams Telšiuose, Vyčio apygardos partizanams Vadokliuose ir t. t.).

6. Paminklų Laisvès kovotojams statymo istorija pagrindinèse Lietuvos miestų aikštėse yra ypač komplikuota. Akivaizdžiai neigiamas vietinių savivaldybių požiūris ị tokių paminklų statymą. Pvz., paminklo Prisikèlimo apygardos partizanams Prisikèlimo aikštejje Šiauliuose statymo istorija, kai tuometinè miesto valdžia oficialiai pareiške, kad turi kitą požiūrị i pokario rezistencijos reiškinį, todèl yra prieš tokių paminklų statymą. Rezultatas - paminklas statomas Šeduvoje, o miestas neteko galimybès už valstybès pinigus sutvarkyti pagrindinę aikštę. Egzistuoja reali tendencija - tokie paminklai ignoruojami. Formaliai Lietuvoje paminklų partizanams daug, bet jie yra smulkūs ir labai nevienodos meninès kokybès. Tai yra suprantama, nes nesant oficialios valdžios palaikymo žmonès dirba taip, kaip išmano.

7.Simbolis „Laisvë“ klaidingai sutapatinamas (arba sąmoningai sutapatintas) su paminklu Laisvès kovų dalyviams. Paprasčiausia sofistika - simbolis „Laisvë“ nereiškia Laisvès kovų ịprasminimo. Tokioje nekonkrečioje sampratoje telpa bet kokia veikla be jokių apribojimų, be jokių ,žaidimo taisyklių“, netgi anarchija. „Laisvès“ samprata palikta kiekvieno individo individualiai sampratai, kuri dažniausiai konstruojama atsiribojimo nuo bet kokių visuomeniškumo formų principais. Konkurso rezultatai tą akivaizdžiai patvirtino.

8. Skirtingai suprantamas galutinis rezultatas - apželdintas plotas, viešoji erdvè, paminklas, simbolinis kapas, reprezentacinè funkcija, požeminis garažas ir t. t. LR Seimo 1999 m. vasario 11 d. nutarimas Nr. VIII - 1070 Dèl valstybès sostinèje esančios Lukiškiu aikštès funkciju faktiškai ignoruojamas.

9. LR Prezidentas V. Adamkus, vetavęs įstatymo projektą dèl Lukiškių aikštès 1996 m., faktiškai sumenkino aikštès statusą iš valstybinio į savivaldybès. Todèl savivaldybès rango politikai ir viešojo administravimo specialistai daugiau užsiiminèjo viešujų ryšių akcijomis negu realiais veiksmais.

\section{Literatūra ir šaltiniai}

Aymonino, A.; Paolo Mosco, V. 2006. Contemporary Public Space. Un - volumetric Architecture. Milano: SKIRA.

Balcerowicz, L. 1998. Socializmas. Kapitalizmas. Transformacija. Vilnius: Algarve, ALK.

Cowan, R. 2005. The Dictionary of Urbanism. Illustrated by L. Rogers, preface by Sir P. Hall. Streetwise Press.

Daunora, Z. J. 1993. Žvèryno rajono erdvinès ir plano struktūros savitumai bei jų respektavimo problema. Vilniaus Žvèryno rajono urbanistiniai tyrimai, VGTU mokslo darbai, Urbanistika ir rajonu planavimas 18: 132-157.

Daunora, Z. J. 1998. Lukiškių aikštès ir jos aplinkos urbanistinès sąlygos ir plètojimo galimybès, Urbanistika ir architektūra XXII(2): 64-76.

Gehl, J.; Gemzøe, L. 2003. New City Spaces. Copenhagen: The Danish Architectural Press.

Gehl, J.; Gemzøe, L.; Kirknǽs, S.; Søndergaard, B. 2006. New City Life. Copenhagen: The Danish Architectural Press.

Grunskis, T. 2007. Diktato architektūra. Lukiškių aikštè, Archiforma 1: 102-105. 
Jokubaitis, A. 2006. Kokia Nepriklausomybès prasmè? Vilnius: Logos.

Kavolis, V. 1995. Kultūrinè psichologija. Vilnius: Baltos lankos.

Krier, L. 1984. Houses, palaces, rities. AD Editions Ltd, London W8.

Lietuvos architektu sajungos Vilniaus skyriaus pirmininko K. Pempès raštas LR Seimo švietimo, mokslo ir kultūros komiteto pirmininkui Ž. Jackūnui. 1999-01-25, Nr. 13. Vilnius.

Lietuvos politinių kalinių ir tremtinių sajungos raštas Nr. 357p, 1999-01-25.

LR Seimo 1999 m. vasario 11 d. nutarimas Nr. VIII - 1070 Dél valstybès sostinejje esančios Lukiškių aikštès funkcijų.

Lukiškiu aikštès ir aplinkos urbanistiniai tyrimai. 1997. VGTU Urbanistikos katedra (temos vadovas prof. dr. Z. J. Daunora).

Lukiškiu aikštés laikinojo sutvarkymo konkurso sąlygos. Patvirtino Vilniaus m. meras R. Paksas (1998-05-14) ir Lietuvos Architektų sąungos pirmininkas L. Vaitys (1998-05-13).

Lukiškiu aikštès suplanavimo ir simbolio „Laisvë“ architektūrinis meninis konkursinis projektas. 2008. VGTU Urbanistikos katedra, Urbanistinès analizès mokslo laboratorija.

Lukiškiu aikštès suplanavimo ir simbolio „Laisve“" sukūrimo architektūrinio meninio projekto konkurso salygos [interaktyvus]. 2006 [žiūrèta 2008-03-20]. Prieiga per internetą: $<$ www.vilnius.lt $>$.

Milčius, P.; Tvaskienè, J. 2003. Andriukaitis taiso Vilniaus veidą, Lietuvos žinios. 2003-02-18, Nr. 40 (10469).

Pilkauskas, R.; Žickis, A. 1996a. Vilniaus kapinių plètotè, Urbanistika ir architektūra 1(21): 30-45.

Pilkauskas, R.; Žickis, A. 1996-04-12b. Centrinis sostinès skveras, Dienovidis, Nr. 15.

Putinaitè, N. 2007. Nenutrūkusi styga. Prisitaikymas ir pasipriešinimas sovietų Lietuvoje, Aidai, 7.

Šešelgis, K. 1997. Vilniaus miesto Lukiškių aikštès formavimo projektai, Urbanistika ir architektūra 2(24): 32-53.

Vilniaus centrinès dalies viešuju erdviu ir prieigu prie Lukiškių aikštès pasiūlymai. 2007. Vilniaus miesto savivaldybè.

Vilniaus miesto Naujamiesčio rajono raidos programa. 2000. St „Vilniaus planas“.

Vilniaus Žvèryno rajono urbanistiniai tyrimai. 1993. VGTU mokslo darbai, Urbanistika ir rajonu planavimas 18. Vilnius: Technika.

Young, J. E. 1993. The Texture of Memory. Holocaust Memorials and Meaning. New Haven and London: Yale University Press.

Zeigler, H. 1993. Politinè bendruomenè (ịvadas ị politiniu sistemu ir visuomenes lyginamaja analize). Kaunas: Littera Universitati Vytauti Magni.

\section{LUKIŠKĖS SQUARE - EVOLUTION OF A SOCIAL ORDER. A MONUMENT TO FIGHTERS FOR FREEDOM OR A SYMBOL "FREEDOM"?}

\section{A. Vyšniūnas}

Abstract. This paper is about public spirit, national monuments and a sign system in Lukiškès Square in Vilnius. Such a system is a part of national Policy, therefore, one should keep distinct the pure artistical and national identity ideas. Nowadays a sense of national pride is very important and at the same time a real problem in Lithuania.

A nation always has an essential place, a system of symbols or an extraordinary monument. Lithuania is only getting ready to consider the issue of monuments and signs in all its aspects. That is why, according to the rules of Lukiškes Square architectural competition, it is demanded to solve this problem. A representative function is required.

"The memory of an unknown partisan and fighter for Lithuania's freedom will be memorialized" a slogan incused on a stone panel proclaims in Lukiškès Square. But there are still no results.

The conception of public space is unidentified, so an urban space and ordinary functional aspects are always muddled up.

West European public space practice indicates that Renaissance squares are the most popular, multifunctional public spaces.

The space system and nominal space hierarchy are very complicated and indefinite, therefore, the final result is under different interpretations. Memorialization of dedication to fighters for Lithuania's freedom is of great importance, but practical square formation aspects, such as parking, fountain construction, etc., are also important.

The Lithuanian Parliament adopted a resolution on Lukiškès Square functions (11 Feb. 1999), but pursuancee belongs to the Municipality. That is a mistake and a real problem because the Municipality's activities are not transparent. Such problems must be solved by a Steering Committee which must be formed. Otherwise a qualitative result is impossible.

In 2008 Lukiškès Square architectural competition was proclaimed. The format of the main task is double - urban and artistical aspects are declared. The result of this competition is an abstract artistical accent, but not a real representative memorial.

The purpose of this work is to reveal the formation process of Lukiškès Square as the main square of Lithuania. The basic principles of the Square formation and those of erecting a monument to the Lithuanian freedom fighters are presented.

Keywords: national self-respect, architectural competition, public relations, artistical accent, symbol, monument, urban structure, monument to fighters for Lituania's freedom.

\section{ALGIS VYŠNIŪNAS}

Assoc Prof, Dept of Urban Design, Vilnius Gediminas Technical University (VGTU), Pylimo g. 26/Traku g. 1, LT-01132 Vilnius, Lithuania.

Teaching: lectures on architectural design, urban planning composition, reconstruction of the city environment and urban structure. Publications: author of about of 19 scientific works and research projects, including "The reconstruction of city living structures", co-author of monograph "Preservation of visual identity of Vilnius city and principles of its development" (2004). Research interests: spatial layout structure of towns and districts, urban structure and morphology. 